\title{
Comprehensive Analysis of the Chemical Composition and In Vitro Cytotoxic Mechanisms of Pallines Spinosa Flower and Leaf Essential Oils Against Breast Cancer Cells
}

\author{
Ayman M. Saleh ${ }^{a}$ Mahmoud A. Al-Qudah ${ }^{b}$ Amre Nasr ${ }^{c}$ Sayed A. Rizvid \\ Anwar Borai ${ }^{a, e}$ Mustafa Daghistani ${ }^{a, e}$ \\ aDepartment of Clinical Laboratory Sciences, College of Applied Medical Sciences, King Saud Bin \\ Abdulaziz University for Health Sciences (KSAU-HS), and King Abdullah International Medical \\ Research Center (KAIMRC), King Abdulaziz Medical City, Ministry of National Guard Health Affairs, \\ Jeddah, Kingdom of Saudi Arabia; ' ${ }^{b}$ Department of Chemistry, Faculty of Science, Yarmouk University, \\ Irbid, Jordan; 'Department of Basic Medical Sciences, College of Medicine, King Saud Bin Abdulaziz \\ University for Health Sciences (KSAU-HS), National Guard Health Affairs, Riyadh, Kingdom of Saudi \\ Arabia; ${ }^{d}$ Department of Pharmaceutical Sciences, College of Pharmacy, Nova Southeastern University \\ (NSU), Fort Lauderdale, Florida, USA; e Department of Pathology and Laboratory Medicine, King \\ Abdulaziz Medical City, Ministry of National Guard Health Affairs, Jeddah, Kingdom of Saudi Arabia
}

\section{Key Words}

Pallines spinosa • Essential oils • Anticancer natural compounds • Apoptosis • Cell cycle • G0/ G1 phase $\cdot$ Cyclin-D $\cdot$ CDK4 $\bullet$ p21 $\bullet$ Breast cancer cell lines

\begin{abstract}
Background/Aims: In our quest for new natural anticancer agents, we studied the cytotoxicity of the essential oils extracted from flowers and leaves of Pallines spinosa. Methods: The essential oils were extracted by hydrodistillation and solid phase microextraction (SPME) from flowers and leaves of the plant and their composition was determined by GC/GC-MS. The cytotoxicity of the oils was evaluated against MCF-7 and MDA-MB-231 breast adenocarcinomas, and the non-cancerous MCF-10-2A cells, using a flow cytometry-based assay. Apoptosis was evaluated by flow cytometry, nuclear staining, caspases activation, and Western blotting techniques, and cell cycle by measuring DNA contents. Results: The hydrodistilled flower oil contained mainly sesquiterpenes (96.39\%), while the leaf sample was dominated by oxygenated-sesquiterpenes (51.60\%) and sesquiterpene-hydrocarbons (34.06\%). In contrast, the SPME oil contained mainly monoterpene-hydrocarbons (44.09\%) and sesquiterpene-hydrocarbons (34.15\%) in the flower and leaf samples, respectively. The cytotoxicity of the flower oil against MCF-7 (IC F $_{50}$ $0.25 \pm 0.03 \mu \mathrm{g} / \mathrm{mL}$ ) and MDA-MB-231 ( $\mathrm{IC}_{50} 0.21 \pm 0.03 \mu \mathrm{g} / \mathrm{mL}$ ) was much stronger than the leaf oil ( $\mathrm{IC}_{50} 2.4 \pm 0.5 \mu \mathrm{g} / \mathrm{mL}$ and $1.5 \pm 0.1 \mu \mathrm{g} / \mathrm{mL}$, respectively). The toxicity of the flower oil was $\sim 5$ to 8-times less in normal MCF-10-2A ( $\mathrm{IC}_{50} 1.3 \pm 0.2 \mu \mathrm{g} / \mathrm{mL}$ ) and blood mononuclear cells $(2.80 \pm 0.45 \mu \mathrm{g} / \mathrm{mL})$ as compared to breast and hematological cancer cells, respectively.

\begin{tabular}{ll}
\hline Ayman M Saleh & King Saud Bin Abdulaziz University for Health Sciences-Jeddah Saudi Arabia) \\
and Mahmoud A Al-Qudah & and Yarmouk University-Irbid (Jordan) \\
& E-Mail salehay@ksau-hs.edu.sa/mahmoud.qudah@yu.edu.jo
\end{tabular}
\end{abstract}




\section{Cellular Physiology Cell Physiol Biochem 2017;42:2043-2065 and Biochemistry Published onlne: August $112017 \quad \begin{aligned} & \text { D } 2017 \text { The Author(s) } \\ & \text { www.karger.com/cpb }\end{aligned}$ \\ Saleh et al.: Anticancer Activity of $P$. Spinosa Essential Oils}

Both oils induced a caspase-dependent and -independent apoptosis in MCF-7 and MDAMB-231 cells, and altered the levels of $\mathrm{BCl}-2$ and Bax proteins. In addition, the oils arrested cell cycle in both cancer cell lines at G0/G1 phase by modulating the expression of cyclin D1, CDK4 and p21 proteins. Conclusion: The cytotoxicity of $P$. spinosa oils were mediated by apoptosis and cell cycle arrest, suggesting the potential use of their bioactive compounds as natural anticancer compounds.

C 2017 The Author(s)

Published by S. Karger AG, Basel

\section{Introduction}

Breast cancer is one of the most reported tumors, and it is the second leading cause of cancer mortality in women worldwide, with more than 255,000 (highest among all types) new cases expected in the United States in $2017[1,2]$. The ductal carcinoma is the most common type (90\%) of non-invasive breast cancer, while lobular carcinoma and inflammatory breast cancer are also reported [3-5]. There are many factors identified in its pathogenesis, including, genetic predisposition, alcohol consumption, diet and obesity, physical inactivity, and endocrine factors $[3,6]$. The most common recommendation of breast cancer management is the surgical removal of the lump (lumpectomy), or the entire breast (mastectomy) depending on the stage. Other treatment modalities include radiation therapy and chemotherapy, they can both be used prior to and after the surgery [6].

Treatment with cytotoxic chemotherapy in both early and advanced stages of breast cancer has made significant progress in the last decade with substantial key studies showing better survival benefits of newer therapies [7]. In spite of improvements with recent synthetic and adjuvant therapies for early stage breast cancer, resistance to therapy remains a major challenge in the management of advanced stages of the disease [7]. Therefore, better understanding of the molecular signaling basis of breast cancer should provide further potential targets for novel therapies.

Alteration of apoptosis, the highly controlled process of programmed cell death, is the main cause of cancer and it is associated with poor chemotherapy outcomes [3]. Herceptin Receptor 2 (HER2) is a trans-membrane receptor tyrosine kinase that activates multiple growth-promoting signaling pathways with a frequently occurrence in breast cancer that causes tumor resistance to treatment with cytotoxic regimen [8]. Hyperactivation or overexpression of this receptor is the primary cause of suppressing apoptosis which leads to enhancing cell survival giving rise to uncontrolled proliferation and tumor growth [8]. Both the extrinsic and intrinsic pathways of apoptosis have been shown to be disrupted in HER2 overexpressing breast cancer cells. HER2 overexpression is associated with increased expression of survivin and decreased response to signaling by cell surface death receptors leading to inhibition of caspases involved in activating the extrinsic pathway of apoptosis [9, 10]. HER2 also increases the expression of anti-apoptotic members of the Bcl-2 family (Bcl-2, $\mathrm{Bcl}-\mathrm{xL}$, and $\mathrm{Mcl}-1$ ), and therefore inhibits the release of cytochrome $\mathrm{c}$ from the mitochondria to activate the Apaf-1/caspase- 9 apoptosome [11]. Moreover, HER2 is able to translocate and sequester cytochrome $\mathrm{c}$ in the mitochondria to prevent its release [12]. HER2 also suppresses p53-mediated apoptosis through upregulating the E3 ubiquitin-protein ligase MDM2 [13].

In addition to evading apoptosis, dysregulation of the cell cycle is a highly common feature of proliferating and metastatic breast tumor cells [14]. Cyclin-dependent kinases (CDKs) are critical regulators of cell cycle progression and their activity is regulated through association with different regulatory cyclin subunits and endogenous cyclin dependent kinase inhibitors (CKIs), as well as by positive and negative phosphorylation events [14]. In malignant mammary cells, altered expression of CDKs and their modulators, including overexpression of cyclins and decreased expression of CKIs result in deregulated CDKactivity leading to loss of cell checkpoint integrity and ultimately uncontrolled cell proliferation [14].

As a way of defensive mechanism, some plants produce toxic secondary metabolites. Some of these compounds pose wide array of pharmacological activities and even found 


\section{Cellular Physiology Cell Physiol Biochem 2017;42:2043-2065 \begin{tabular}{ll|l} 
and Biochemistry Published onlne: August 112017 & $\begin{array}{l}\text { O 2017 The Author(s). Published by S. Karger AG, Basel } \\
\text { www.karger.com/cpb }\end{array}$ \\
\hline
\end{tabular} \\ Saleh et al.: Anticancer Activity of $P$. Spinosa Essential Oils}

to be more toxic for cancer cells compared to the normal cells [15]. These compounds often become a source of new and better drugs via rational design in medicinal chemistry [15]. Essential oils are composed of low molecular weight aromatic compounds such as terpenoid hydrocarbons, oxygenated terpenes, and sesquiterpenes [16]. There are about 3000 essential oils reported and 10\% ( 300) of those are used in various pharmaceutical, cosmetics, agrochemical and food industries. Recently, extensive efforts have been used in evaluating the cytotoxic capacity of essential oils, and particular focusing on those modulating apoptosis and cell cycle progression for their potential applications in cancer prevention and treatment $[15,16]$.

The classical techniques for the determination of plant essential oils composition utilize two steps: extraction (solvent-based, steam distillation, hydrodistillation and solid phase microextraction, SPME) and both qualitative and quantitative analysis (gas chromatography (GC) or GC-mass spectrometry (GC-MS) [17]. The identity and possibly the quantity of the compounds in essential oils depend on the extraction method used. Solvent extracted oil may contain non-volatile compounds that affect the analysis step by GC and GC-MS. Steam distillation process is performed at $100^{\circ} \mathrm{C}$ causing loss of several volatile components. Although hydrodistillation technique is more preferred over steam distillation, it has the disadvantage of potential thermal degradation of some compounds due to the long heating period during extraction. On the other hand, the headspace SPME (will be referred here as SPME) is the most advanced technique that is able to extract and concentrate analytes of different volatility, including trace essential oil substances from a very little amount of plant material [17]. However, SPME is limited to compositional analysis rather than providing essential oil for other purposes.

Pallenis spinosa (L.) de Cassini (family; Asteraceae), commonly known as the Spiny Starwort, is an annual herbaceous plant that grows in vast areas of Jordan and the Middle East region [18]. This plant has been known and used for the treatment of eczema, rheumatism, muscular contraction, gastralgia, diabetes, headaches, skin injuries, and infections [19, 20]. Secondary metabolites identified in this plant include sesquiterpenes and oxygenated sesquiterpenoids [21]. The hydrodistilled volatile oil from P. spinosa flower-heads collected in Italy contains high percentages of oxygenated sesquiterpenoids, such as germacra-1(10),5dien-3,4-diol, $\alpha$-cadinol, 3-acetoxygermacra-1(10),5-dien-4-ol, T-cadinol and $\delta$-cadinene [21]. However, up to date, the biological activities of the plant have not been documented.

In the present study we aimed to determine the detailed composition of P. spinosa flower and leaf essential oils extracted by hydrodistillation and SPME, and evaluate their anticancer potential against the human hormone-sensitive MCF-7 and -insensitive MDA-MB-231 breast cancer cells. This report also aimed to confirm that the cytotoxic potential of the oils was mediated by apoptosis and cell cycle disruption in both cancer cell lines.

\section{Material and Methods}

\section{Reagents}

GC grade $n$-hexane, $\mathrm{C}_{8}-\mathrm{C}_{20} n$-alkanes, dimethyl sulfoxide (DMSO), doxorubicin, RIPA cell lysis buffer, Tris-hydrochloride, bovine serum albumin (fraction V), protease inhibitors (PMSF, pepstatin A, leupeptin, and aprotinin) and Hoechst 33342 stain were acquired from Sigma Aldrich (St Louis, Missouri, USA). Anhydrous sodium sulfate was purchased from UCB (Bruxelles, Belgium). Cell culture media (DMEM, DMEM/F12, IMDM, RPMI 1640 and Leibovitz's L-15), penicillin-streptomycin, trypsin, phosphate buffered saline (PBS), heat inactivated fetal bovine serum (FBS), horse serum, insulin, epithelial growth factor (EGF), cholera toxin, hydrocortisone, sodium pyruvate, Glutamax® and non-essential amino acids were purchased from Invitrogen (Invitrogen, Carlsbad, California, USA). Cell culture grade disposable and materials are from Corning Life Sciences (Tewksbury, Massachusetts, USA). The colorimetric tetrapeptide substrate for caspas-3/-7 (Ac-DEVD- $p$ NA) and the general caspase inhibitor (z-VAD-FMK) were purchased from BioVision, Inc. (Milpitas, California, USA). The primary antibodies against [cleaved form of caspase-3 (p19) and poly-ADP-ribose polymerase (PARP), from apoptosis antibody sampler kit \# 9915], Bcl-2 family members; [(Bcl-2 and Bcl-X $\mathrm{L}_{\mathrm{L}}$, from the pro-survival Bcl-2-family antibody sampler kit \# 9941] and 


\section{Cellular Physiology Cell Physiol Biochem 2017;42:2043-2065 \begin{tabular}{l|l|l} 
and Biochemistry $10.1159 / 000479900$ & $\begin{array}{l}\text { O 2017 The Author(s). Published by S. Karger AG, Basel } \\
\text { www.karger.com/cpb }\end{array}$ \\
\hline
\end{tabular}}

Saleh et al.: Anticancer Activity of $P$. Spinosa Essential Oils

[(Bax and Bak), from the pro-apoptosis Bcl-2-Family antibody sampler kit \# 9942], cyclins [(cyclin D1, cyclin D2, cyclin D3 and cyclin E), from cyclin antibody sampler kit \# 9869], cyclin-dependent kinases (CDK2, CDK4, CDK6) and cyclin dependent kinase inhibitors (p21 and p27) [from cell cycle regulation antibody sampler kit \# 9932] were all obtained from Cell Signaling Technology (Beverly, Massachusetts, USA), while the one for $\beta$-actin was from Sigma Aldrich (\# A5316). The secondary anti-mouse (\# 7076) and anti-rabbit (\# 7074) IgG antibodies conjugated to Horseradish peroxidase (HRP) were from Cell Signaling Technology.

Plant material and extraction of essential oils

Fresh flowers and leaves of Pallenis spinosa were collected from "Kufor Asad" Town, located $15 \mathrm{Km}$ to the west of Irbid City in northern area of Jordan, in April, 2015. The plant was classified by a botanist, and a voucher specimen (No YU/68/CP/1001) was deposited in the herbarium of the Department of Biological Sciences, Yarmouk University, Irbid, Jordan as a reference. $300 \mathrm{~g}$ of the plant flowers and leaves were washed with double distilled water, then directly chilled in liquid nitrogen and powdered using a mortar and pestle. Subsequently, each powdered plant material was hydrodistilled in $300 \mathrm{~mL}$ distilled water using a Clevenger apparatus [22]. The hydrodistillation process was continued for $3 \mathrm{~h}$ after appearance of first drop of distillate. The collected oil was dried over anhydrous sodium sulfate to remove any residual water, filtered and then immediately stored in GC-grade $n$-hexane at $4{ }^{\circ} \mathrm{C}$ until used for GC and GC-MS analysis. The hydrodistilled essential oil yield was $0.12 \%$ from the flowers (F-PSEO) and $0.08 \% \mathrm{w} / \mathrm{w}$ from the leaves (L-PSEO) of the plant. The density of F-PSEO and L-PSEO was $0.9352 \mathrm{~g} / \mathrm{mL}$ and $0.9275 \mathrm{~g} / \mathrm{mL}$, respectively. For all the biological assays down below, stock solutions of $1000 \mathrm{X}$ of different concentrations of F-PSEO and L-PSEO were prepared in DMSO and stored at $-20^{\circ} \mathrm{C}$ until used.

SPME of volatile oils was performed manually using a partially cross-linked polydimethylsilocane/ divenylbenzene (PDMS/DVB) fiber assembly $(1.0 \mathrm{~cm}$ long and a $65 \mu \mathrm{m}$ thick, Supelco Inc., Bellefonte, Pennsylvania, USA). The fiber was conditioned as per the manufacturer's instructions. The fiber was immersed in a special tightly capped $4.0 \mathrm{~mL}$ amber glass vial containing $0.1 \mathrm{mg}$ of freshly minced flower or leaf of $P$. spinosa to trap the volatile compounds. Trapping and concentration of the volatile constituents by the fiber was allowed to take place for $2 \mathrm{~min}$ inside the vial at room temperature. Subsequently, the analytes were desorbed at $240^{\circ} \mathrm{C}$ for $2 \mathrm{~min}$ and analyzed by GC-MS.

GC and GC-MS Analysis of oil composition

Aliquots, $1 \mu \mathrm{L}$ of each oil sample, were diluted to $10 \mu \mathrm{L}$ of GC-grade $n$-hexane, and subjected to a coupled GC-MS analysis using Varian Chrompack CP-3800 GC/MS/MS-200 (Saturn, Netherlands) equipped with DP-5 (5 \% diphenyl, $95 \%$ dimethyl polysiloxane) GC capillary column (30 m × 0.25 mm i.d., $0.25 \mu \mathrm{m}$ film thicknesses), with helium as an auxiliary carrier gas at a flow rate of $0.9 \mathrm{~mL} / \mathrm{min}$. The actual temperature in MS source reached $180^{\circ} \mathrm{C}$ and the ionization voltage was $70 \mathrm{eV}$. The column temperature was kept at $60^{\circ} \mathrm{C}$ for $1 \mathrm{~min}$, and then programmed to rise to $246^{\circ} \mathrm{C}$ at a constant rate of $3^{\circ} \mathrm{C} / \mathrm{min}$, then maintained at $246^{\circ} \mathrm{C}$ for 3 minutes. A hydrocarbon mixture of $n$-alkanes (C8-C20) was analyzed separately by GC-MS under similar chromatographic conditions using the DP- 5 column. Identification of the oil components was achieved by comparing their relative retention indices (RI) with known mass spectral data [23], the data base National Institute of Standards and Technology (NIST, Gaithhersburg, MD) [24] and our own libraries. A mixture of $n$-alkanes (C8-C20) was used as reference for the calculation of relative retention indices (RI) in temperature-programmed run using column of identical polarity [22]. Quantitative analysis (\% of area) was performed using Hewlett-Packard HP-8590 gas chromatograph (Hewlett-Packard Co., Palo Alto, California, USA) equipped with a split-splitless injector (split ratio 1:50) and a FID detector. An optima-5 (5 \% diphenyl, $95 \%$ dimethyl polysiloxan) fused silica capillary column $(30.0 \mathrm{~m} \times 0.25 \mathrm{~mm}, 0.25 \mu \mathrm{m}$ film thickness; Sorbent Technologies Inc., Norcross, Georgia, USA) was used. The temperature of the oven was gradually increased at a steady rate of $10^{\circ} \mathrm{C} / \mathrm{min}$ between $60^{\circ} \mathrm{C}$ and $250^{\circ} \mathrm{C}$ then held at $250^{\circ} \mathrm{C}$ for $5 \mathrm{~min}$. The temperature of the injector port and detector was maintained at $250^{\circ} \mathrm{C}$ and $300^{\circ} \mathrm{C}$, respectively. The relative peak areas of the oil components were measured and used to extrapolate the concentration of the detected compounds.

Cell culture conditions

The estrogen receptor positive (ER+) MCF-7 (ATCC ${ }^{\circledR} \mathrm{HTB}^{+} 22^{\mathrm{m}}$ ) and negative (ER) MDA-MB-231 (ATCC ${ }^{\circledR}$ HTB-26 $6^{\mathrm{m}}$ ) breast epithelial adenocarcinoma cell lines, as well as immortalized normal breast epithelial MCF-10-2A ((ATCC ${ }^{\circledR}$ CRL-10781 $^{\mathrm{m}}$ ) cell lines were obtained from American Type Culture Collection (ATCC; KARGER 


\section{Cellular Physiology Cell Physiol Biochem 2017;42:2043-2065 \begin{tabular}{ll|l} 
and Biochemistry & Dublished online: August 112017 & $\begin{array}{l}\text { O } 2017 \text { The Author(s). Published by S. Karger AG, Basel } \\
\text { www.karger.com/cpb }\end{array}$ \\
\hline
\end{tabular}}

Saleh et al.: Anticancer Activity of $P$. Spinosa Essential Oils

Manassas, Virginia, USA). Additional ATCC human cells used in this study included; the biphenotypic B myelomonocytic leukemia MV4-11 (CRL-9591 ${ }^{\mathrm{m}}$ ), acute promyelocytic leukemia HL-60 (CCL-240"m), chronic myelogenous leukemia K562 (CCL-243 ${ }^{\mathrm{m}}$ ), acute T lymphocytic leukemia Jurkat, (TIB-152 ${ }^{\mathrm{m}}$ ), acute monocytic leukemia THP-1 (TIB-202 ${ }^{\mathrm{m}}$ ) and myeloid histiocytic lymphoma U937 (CRL-1593.2 ${ }^{\mathrm{m}}$ ). MCF-7 cells were cultured in DMEM medium supplemented with $10 \%(\mathrm{v} / \mathrm{v})$ heat inactivated FBS, $1 \mathrm{mM}$ sodium pyruvate, $1 \%$ non-essential amino acids and $10 \mathrm{ng} / \mathrm{ml}$ insulin. MDA-MB-231cells were maintained in Leibovitz's L-15 medium containing 10\% heat inactivated FBS. The immortalized normal MCF-10-2A breast cell line was grown in DMEM/F-12 having 5\% horse serum, $20 \mathrm{ng} / \mathrm{ml} \mathrm{EGF,} 100 \mathrm{ng} / \mathrm{ml}$ cholera toxin, $10 \mathrm{ng} / \mathrm{ml}$ insulin, and $500 \mathrm{ng} / \mathrm{ml}$ hydrocortisone. Hematological cancer cell lines (HL-60, K562, Jurkat, THP-1 and U937), were cultured in RPMI-1640 medium supplemented with 10\% heat inactivated FBS, while MV4-11 was grown in IMDM medium. All cell culture media contained penicillin G $(100 \mathrm{U} / \mathrm{mL})$ and streptomycin $(100$ $\mathrm{mg} / \mathrm{mL}$ ). Cells were kept at $37^{\circ} \mathrm{C}$ in a $5 \% \mathrm{CO} 2 / 95 \%$ humidified incubator, and passaged when they reached $70 \%$ confluency. Cells were seeded at an appropriate density according to each experimental design.

Isolation of peripheral blood mononuclear cells (PB-MNC)

Isolation of (PB-MNCs) from a $15 \mathrm{~mL}$ peripheral blood sample of a healthy donor, collected in EDTA

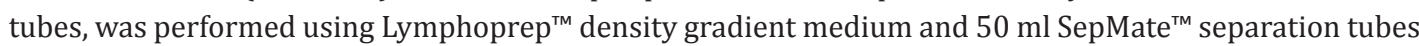
(STEMCELL Technologies Inc., Vancouver, British Colombia, Canada) as described in our recent publication [25] After the separation, PB-MNC were suspended in RPMI-1640 medium at a concentration of $1 \times 10^{5}$ cells $/ \mathrm{mL}$ and cultured in 48-well plates for $6 \mathrm{~h}$ before treatment with the different concentrations of F-PSEO and L-PSEO.

\section{Cell viability (cytotoxicity) assay}

The quantitative determination of viable cells after various treatments with F-PSEO and L-PSEO was performed after staining with the dual DNA intercalating fluorescent dyes kit from EMD Millipore Bioscience (Muse ${ }^{\text {tw }}$ Cell Count \& Viability Assay) as described in our recent publications [26, 27]. Briefly, $4 \times 10^{4} \mathrm{MCF}-7$, MDA-MB-231 and MCF-10-2A cells/mL, or $3 \times 10^{5}$ cells $/ \mathrm{mL}$ of each of the hematological cell lines and $1 \times 10^{5}$ cells $/ \mathrm{mL}$ of PB-MNCs, were treated with increasing concentrations of F-PSEO or L-PSEO (0.1 to $10.0 \mu \mathrm{g} / \mathrm{mL})$ for $48 \mathrm{~h}$. Subsequently, samples were incubated with the Cell Count \& Viability reagent for $5 \mathrm{~min}$, and the viability of treated cells were analyzed using the flow cytometry-based Muse $\mathrm{e}^{\text {tw }}$ Cell Analyzer (EMD Millipore Bioscience, Darmstadt, Germany) according to the manufacture's protocol. The cell viability was calculated as percentages to live cells compared to untreated control samples containing the carrier solvent DMSO. Under similar conditions, cells were exposed to different concentrations of doxorubicin $(1.0$ to $10.0 \mu \mathrm{g} / \mathrm{mL})$, to serve as a positive control for validating of the assay results.

\section{Analysis of apoptosis by flow cytometry}

The percentage of MCF-7 and MDA-MB-231 cells undergoing apoptosis after treatment with increasing concentrations of the essential oils was determined by using the Muse ${ }^{\mathrm{m}}$ Annexin-V \& Dead Cell Assay kit (EMD Millipore Bioscience, Darmstadt, Germany) according to the manufacturer's protocol. The kit utilizes a fluorescent dye (FITC) conjugated to annexin- $V$ to detect phosphatidylserine (PS) on the external membrane of apoptotic cells and 7-AAD (7-amino-actinomycin D) as dead cells marker. 7-AAD is excluded from living healthy cells, as well as early apoptotic cells. Percentages of cells in early (annexin$\mathrm{V}^{\text {+ve }} / 7-\mathrm{AAD}^{-\mathrm{ve}}$ ) and late stages of apoptosis (annexin- $\mathrm{V}^{\text {+ve }} / 7-\mathrm{AAD}^{\text {+ve }}$ ) were determined by a flow cytometerbased instrument (Muse ${ }^{\text {tm }}$ Cell Analyzer) as previously described [26, 27]. In all experiments, the solvent DMSO concentration was $\leq 0.1 \%$. Similar concentrations of DMSO were added to the control of untreated cells. Both breast cancer cells were also treated with $5.0 \mu \mathrm{g} / \mathrm{mL}$ doxorubicin as an internal positive control to validate the apoptosis results.

\section{Evaluation of nuclear condensation by Hoechst 33342 staining}

Breast cancer cells were seeded at a concentration of $1 \times 10^{4}$ cells $/ \mathrm{mL}$ in an eight-well chamber slide and treated with $0.3 \mu \mathrm{g} / \mathrm{mL}$ of F-PSEO (for both MCF-7 and MDA-MB-231 cells), $2.5 \mu \mathrm{g} / \mathrm{mL}$ and $1.5 \mu \mathrm{g} / \mathrm{mL}$ of L-PSEO (for MCF-7 and MDA-MB-231 cells, respective) or the carrier solvent DMSO (control). After $48 \mathrm{~h}$, the cells were washed with PBS and fixed with $100 \mu \mathrm{L}$ of $1 \%$ glutaraldehyde solution for 30 min. Glutaraldehyde was then removed, and the cells were incubated with $40 \mu \mathrm{L}$ of the DNA-specific dye Hoechst 33342 (1.0 mg/ $\mathrm{mL}$ ). Morphological changes were observed under Nikon Eclipse $90 \mathrm{i}^{\circledR}$ digital fluorescent microscope at a 600X magnification power (Nikon Instruments Inc., Melville, New York, USA). 


\section{Cellular Physiology Cell Physiol Biochem 2017;42:2043-2065 \begin{tabular}{l|l|l} 
and Biochemistry Publisned onlne: August 112017 & $\begin{array}{l}\text { () } 2017 \text { The Author(s). Published by S. Karger AG, Basel } \\
\text { www.karger.com/cpb }\end{array}$ \\
\hline
\end{tabular}}

Saleh et al.: Anticancer Activity of $P$. Spinosa Essential Oils

Measuring caspase-3/-7 enzymatic activities

The enzymatic activities of caspase-3/-7 were determined spectrophotometrically in $20 \mu \mathrm{g}$ of MCF-7 and MDA-MB-231 lysates after treating the cells with proper concentrations of F-PSEO, L-PSEO or doxorubicin in the presence or absence of $60 \mu \mathrm{M}$ of the general caspases inhibitor z-VAD-FMK. The assays were performed using the caspase-specific colorimetric tetrapeptide substrate Ac-DEVD-pNA as previously described in details [26-28].

Flow cytometry analysis of cell cycle

MCF-7 and MDA-MB-231 cells were seeded in 6-well plates at a density of $3 \times 10^{5}$ cells $/ \mathrm{mL}$ in their appropriate media and incubated for $12 \mathrm{~h}$. Then, the cells were exposed for $24 \mathrm{~h}$ to increased concentrations of F-PSEO and L-PSEO (0.1-5.0 $\mu \mathrm{g} / \mathrm{mL})$. Cells in different stages of cell cycle were analyzed by flow cytometry using the Muse ${ }^{\mathrm{TM}}$ Cell Cycle Kit from EMD Millipore Bioscience (Darmstadt, Germany). The kit utilizes propidium iodide (PI) staining to allow quantitative measurements of percentage of cells in the G0/G1, S and G2/M phases on the Muse ${ }^{\mathrm{TM}}$ Cell Analyzer (EMD Millipore Bioscience). The cell cycle analysis was performed according to the manufacturer's protocol, and as detailed in our recent reports [27, 29]. Briefly, after incubation with the oils, cells were harvested and washed with PBS, followed by fixation with ice-cold $70 \%$ ethanol at $-20^{\circ} \mathrm{C}$ for $3 \mathrm{~h}$. Subsequently, cells were washed with PBS, stained with $200 \mu \mathrm{L}$ of PI/RNAse reagent for $30 \mathrm{~min}$ and analyzed by the Muse ${ }^{\mathrm{m}}$ Cell Analyzer. The control cells were treated with equal amount of the carrier solvent ( $0.1 \%$ DMSO), and showed no effect on cell cycle when compared with the solvent-free control cells (not shown). Under similar conditions, cells were treated with $2.0 \mu \mathrm{g} / \mathrm{mL}$ and $5.0 \mu \mathrm{g} / \mathrm{mL}$ doxorubicin as internal controls to validate the assay results (not shown).

Western blot analyses

Sample preparation after treatment with the oils, primary antibodies used in this study and Western blot analysis were performed according to manufacturer's protocols and as previously described in detail $[26,29]$. The density of visualized bands was quantitated by UN-SCAN-IT 7.0 gel and graph digitizing software and expressed as a relative-fold to untreated control in two independent experiments.

\section{Statistical analysis}

Data presented are the means \pm S.D. of results from a minimum of three independent experiments with similar patterns. Statistical analysis was performed using one-way ANOVA and Student's t-test with the aid of GraphPad Prism 6 software. A $p$ value $<0.05$ was considered statistically significant.

\section{Results}

Composition of the essential oils extracted by hydrodistillation and SPME

The volatile components from flowers and leaves of $P$. spinosa were extracted by hydrodistillation and SPME, and their identities were determined by GC/MS as described under the method section. Representative GC chromatograms for F-PSEO and L-PSEO extracted by hydrodistillation and SPME are shown in Fig. 1A and Fig 1B, respectively. The hydrodistilled flowers and leaves yielded $0.12 \%$ and $0.08 \%$ of F-PSEO and L-PSEO, respectively. Thirty-eight in F-PSEO and eighty-six compounds in L-PSEO were identified by GC-FID accounting for $99.77 \%$, and $98.69 \%$ of the total oils, respectively (Table 1). F-PSEO mostly contained sesquiterpenoids (96.39\%), specifically, $78.63 \%$ of the oil constituents were oxygenated derivatives. This class of compounds in F-PSEO included acorenone B (33.85\%), $\alpha$-muurolol $(21.93 \%), \alpha$-cadinol $(8.54 \%)$, oplopanonyl acetate $(7.22 \%), \delta$-cadinene $(4.95 \%)$ and germacrene-D-4-ol (4.28\%). In contrast, L-PSEO was dominated by two groups of compounds: oxygenated sesquiterpenes (51.60\%) followed by sesquiterpene hydrocarbons (34.06\%). The oxygenated sesquiterpenes [ $\alpha$-cadinol (13.15\%), acorenone B $(9.64 \%)$ and $\alpha$-muurolol $(9.83 \%)]$ and the sesquiterpene hydrocarbons $[\beta$-longipinene $(6.26 \%)$ and $\delta$-Cadinene $(5.79 \%)]$ were the most abundant compounds of these two groups in leaf oil.

On the other hand, GC/MS analysis of the volatile oils extracted by SPME technique identified fifty-nine in F-PSEO and fifty-two compounds is L-PSEO, constituting 97.60\% and $98.42 \%$ of the total oils respectively (Table 1$)$. The cyclic monoterpenes $p$-cymene $(27.76 \%)$ and $\alpha$-phellandrene (13.59\%), the sesquiterpene hydrocarbon $\beta$-caryophyllene $(6.33 \%)$, 


\section{Cellular Physiology Cell Physiol Biochem 2017;42:2043-2065 \begin{tabular}{ll|l} 
and Biochemistry $10.1159 / 000479900$ & $\begin{array}{l}\text { C } 2017 \text { The Author(s). Published by S. Karger AG, Basel } \\
\text { www.karger.com/cpb }\end{array}$ \\
\hline
\end{tabular} \\ Saleh et al.: Anticancer Activity of $P$. Spinosa Essential Oils}

Fig. 1. Representative GC chromatograms obtained for F-PSEO and L-PSEO by hydrodistillation and SPME. The numbers above the peaks indicate the major identified compounds that are listed by the same numbers in Table 1.

the oxygenated monoterpene thymol methyl ether $(6.04 \%)$ and the sesquiterpene hydrocarbon $\beta$-selinene $(6.02 \%)$ were the major components in F-PSEO. However, the prominent compounds in L-PSEO were the sesquiterpene hydrocarbon persilphiperfol-7-ene (23.84\%), the oxygenated monoterpene 1,8-cineole $(6.17 \%)$ and the monoterpene hydrocarbons $[\beta$-pinene $(5.84 \%), \quad p$-cymene (5.56\%), $\alpha$-pinene (4.91\%) and $\alpha$-terpinene (4.49\%)].

In general, there was a compositional and quantitative variation between
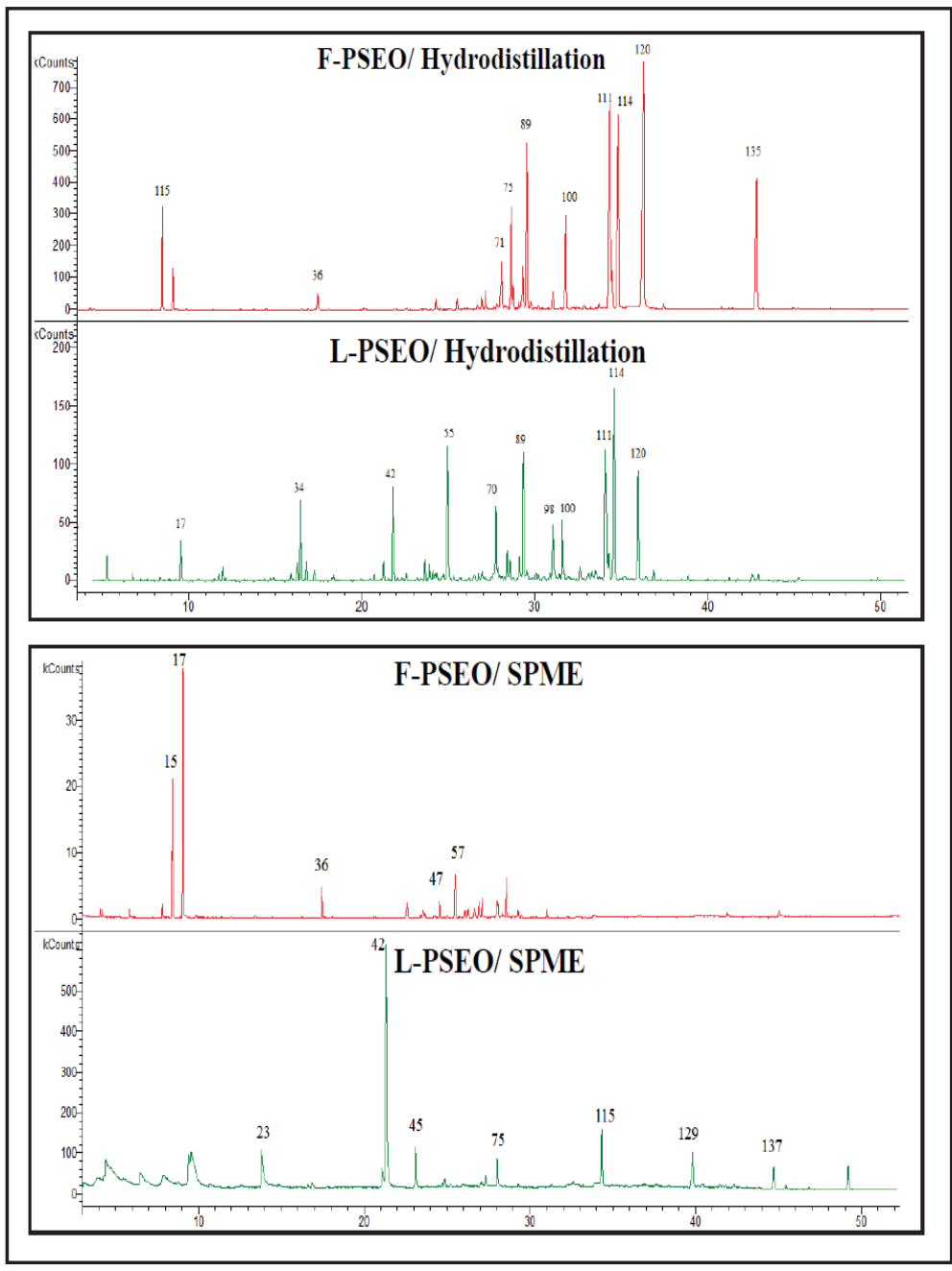

the oils extracted by SPME and hydrodistillation techniques. The percentage of monoterpene hydrocarbons in SPME-F-PSEO (44.09\%) and -L-PSEO $(22.27 \%)$ samples was greater than the oils extracted by hydrodistillation $(3.07 \%$ and $0.57 \%$, respectively). The sesquiterpene hydrocarbons and oxygenated monoterpenes were also detected at higher percentage in SPME-F-PSEO (38.64\% and 8.82\%, respectively) and -L-PSEO (34.15\% and $10.61 \%$ ) as compared to hydrodistilled-flower (17.76\% and $0.70 \%)$ and -leaf oils $(34.06 \%$ and $6.66 \%)$. Conversely, the hydrodistillation was more effective in extracting oxygenated sesquiterpenes than the SPME method from both flowers $(78.63 \%$ vs.1.53\%) and leaves $(51.60 \%$ vs.15.50\%) of P. spinosa.

\section{Cytotoxicity of F-PSEO and L-PSEO against breast cancer and normal cell lines}

Several previous studies have shown that many plant essential oils possess a potent anticancer activity against different cancer cell lines $[15,16]$. To investigate the cytotoxic activities of F-PSEO and L-PSEO, the human MCF-7 and MDA-MB-231 cells were exposed to increasing concentrations of the essential oils $(0.1-10.0 \mu \mathrm{g} / \mathrm{mL})$ for $48 \mathrm{~h}$ and the viability was determined by flow cytometry after staining with the dual DNA fluorescent dyes as described under the method section. As demonstrated in Fig. 2A and 2B, low doses of F-PSEO and L-PSEO were able to effectively inhibit the growth of both cultured cancer cells in a dose-dependent manner. However, F-PSEO showed much greater cytotoxic effect than L-PSEO. For example, $1.0 \mu \mathrm{g} / \mathrm{mL}$ of F-PSEO and L-PSEO were able to reduce the cellular viability of MCF-7 from $93.5 \pm 2.5 \%$, in the untreated control, to $5.5 \pm 3.3 \%$ and $64.5 \pm 4.2 \%$, respectively (Fig. 2A). Similarly, F-PSEO and L-PSEO suppressed the growth of MDA-MB-231 cells from 91.6 
Cell Physiol Biochem 2017;42:2043-2065

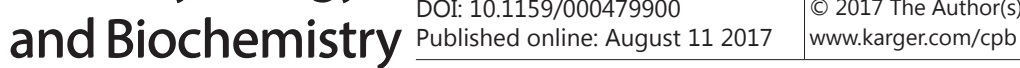

Saleh et al.: Anticancer Activity of $P$. Spinosa Essential Oils

$\pm 2.8 \%$ (untreated control) to $3.5 \pm 2.9 \%$ and $47.7 \pm 4.1 \%$, respectively (Fig. 2B). Interestingly, MDA-MB-231 cells were more sensitive to exposure to either oil than MCF7 cells treated under similar conditions. The $\mathrm{IC}_{50}$ for F-PSEO and L-PSEO in MDAMB-231 cells were $0.21 \pm 0.03$ $\mu \mathrm{g} / \mathrm{mL}$ and $1.5 \pm 0.10 \mu \mathrm{g} / \mathrm{mL}$ (Fig. 2B), compared to 0.25 $\pm 0.03 \mu \mathrm{g} / \mathrm{mL}$ and $2.4 \pm 0.50$ $\mu \mathrm{g} / \mathrm{mL}$ in MCF-7 (Fig. 2A), respectively. Interestingly, when compared with the inhibitory doses against the two breast cancer cells, both F-PSEO and L-PSEO showed a much lower toxicity in the noncancerous breast epithelial cells MCF-102A grown under similar conditions (Fig. 2C). The $\mathrm{IC}_{50}$ for the F-PSEO in MCF-10-2A was at least 5-fold greater than any of the breast cancer cells, while L-PSEO showed only $\sim 1.5$ to 2 -fold difference, suggesting that the toxicity of the oils is more selective towards malignant cells (Fig. 2C). In contrast, the $\mathrm{IC}_{50}$ for the positive control doxorubicin was $4.0 \pm 1.0 \mu \mathrm{g} / \mathrm{mL}$ in MCF-7, 1.8 $\pm 0.5 \mu \mathrm{g} / \mathrm{mL}$ in MDA-MB-231 and $8.3 \pm 2.2 \mu \mathrm{g} / \mathrm{mL}$ in MCF10-2A, indicating a comparatively stronger cytotoxicity and better efficacy exhibited by the oil against cancer cells. The cytotoxicity of both oils was also examined against other cancer cell lines (Table 2). The $\mathrm{IC}_{50}$ for F-PSEO and L-PSEO against various hematological cancer cell lines (MV4-11, HL-60, K562, Jurkat, THP-1 and U937) ranged from $0.09 \pm 0.02 \mu \mathrm{g} / \mathrm{mL}$ to $0.33 \pm$ $0.08 \mu \mathrm{g} / \mathrm{mL}$ (for F-PSEO) and $0.22 \pm 0.05 \mu \mathrm{g} / \mathrm{mL}$ to $1.27 \pm$ $0.31 \mu \mathrm{g} / \mathrm{mL}$ (for L-PSEO), while in PB-MNCs from healthy individuals was $2.80 \pm 0.45$
Table 1. Chemical composition (\%) of F-PSEO and L-PSEO extracted by hydrodistillation and SPME from $P$. spinosa

\begin{tabular}{|c|c|c|c|c|c|}
\hline \multirow{2}{*}{ Compound } & \multirow[t]{2}{*}{$\mathrm{RRI}^{1}$} & \multicolumn{2}{|c|}{ F-PSEO (\%) } & \multicolumn{2}{|c|}{ L-PSEO (\%) } \\
\hline & & H-DST ${ }^{2}$ & SPME & H-DST & SPME \\
\hline 1-Octene & 800 & -3 & 0.67 & 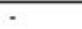 & - \\
\hline Ethyl butanoate & 809 & - & 0.55 & . & . \\
\hline 2Z-Octene & 814 & 0.1 & 0.13 & - & - \\
\hline 2E-Hexenal & 855 & - & 0.14 & . & 1.99 \\
\hline 3Z-Hexenol & 859 & - & - & - & 2.87 \\
\hline Methyl tiglate & 878 & - & 0.2 & - & 1.67 \\
\hline Ethyl pentanoate & 891 & - & 0.13 & - & - \\
\hline Nonane & 900 & . & 0.29 & . & . \\
\hline Ethyl tiglate & 921 & - & 1.4 & - & - \\
\hline Alpha-pinene & 932 & - & 0.2 & - & 4.91 \\
\hline Benzaldehyde & 960 & - & - & 0.2 & - \\
\hline Sabinene & 967 & - & 0.16 & - & 0.19 \\
\hline$\beta$-Pinene & 987 & - & 1.48 & . & 5.84 \\
\hline Mesitylene & 994 & - & 0.24 & - & - \\
\hline n-Octanal & 999 & - & 0.28 & - & - \\
\hline$\alpha$-Phellandrene & 1007 & 1.74 & 13.59 & 0.36 & 1.08 \\
\hline$\alpha$-Terpinene & 1018 & - & - & - & 4.49 \\
\hline $\mathrm{p}$-Cymene & 1024 & 1.33 & 27.76 & 0.1 & 5.56 \\
\hline 1,8-Cineole & 1030 & - & - & 0.29 & 6.17 \\
\hline Benzenacetaldehyde & 1041 & - & - & 1.67 & - \\
\hline E- $\beta$-Ocimene & 1044 & - & 0.4 & - & - \\
\hline$\gamma$-Tepinene & 1054 & - & 0.14 & - & 0.2 \\
\hline Isobutyl tiglate & 1092 & - & - & 0.13 & \\
\hline Linalool & 1099 & - & - & 0.33 & 3.43 \\
\hline cis-Thujone & 1104 & - & . & 0.57 & . \\
\hline 2,6-Dimethyl phenol & 1109 & - & - & 0.14 & - \\
\hline 1,3,8-Para-menthatriene & 1118 & - & 0.12 & - & - \\
\hline Methyl octanoate & 1135 & - & 0.25 & - & 0.51 \\
\hline$\beta$-Pinene oxide & 1159 & - & - & - & 0.18 \\
\hline Ethyl benzoate & 1173 & - & . & 0.11 & \\
\hline Neoiso-isopulegol & 1177 & - & 0.13 & - & - \\
\hline Iso-pinocampheol & 1181 & - & 0.12 & - & - \\
\hline Safranal & 1197 & - & - & 0.38 & - \\
\hline $\mathrm{n}$-Dodecane & 1200 & - & 0.18 & 0.85 & . \\
\hline trans-Pulegol & 1210 & - & - & 2.85 & - \\
\hline trans-Carveol & 1221 & . & 0.13 & 0.74 & . \\
\hline Methyl ether thymol & 1228 & 0.71 & 6.04 & 0.41 & 0.33 \\
\hline Cumin aldehyde & 1242 & - & 0.17 & 0.1 & 0.1 \\
\hline Thymol & 1289 & - & - & 0.14 & 0.4 \\
\hline p-Methoxy acetophenone & 1303 & - & - & 0.31 & 2.12 \\
\hline$z$-Patchenol & 1321 & - & - & 0.7 & - \\
\hline Silphiperfol-5-ene & 1327 & . & - & 0.17 & . \\
\hline Persilphiperfol-7-ene & 1347 & - & 2.35 & 3.17 & 23.84 \\
\hline$\delta$-Elemene & 1330 & - & - & 0.3 & - \\
\hline Evodone & 1340 & - & - & 0.15 & - \\
\hline$\alpha$-Cubebene & 1350 & - & - & 0.53 & 3.82 \\
\hline Cyclsativene & 1366 & - & 0.42 & & - \\
\hline Longicyclene & 1370 & - & 1.15 & 0.71 & 0.1 \\
\hline$\alpha$-Ylangene & 1373 & - & 0.91 & - & - \\
\hline $\mathrm{z}$ - $\beta$-Damascone & 1383 & - & - & 0.86 & \\
\hline$\beta$-Elemene & 1388 & 0.17 & 0.28 & 0.46 & 0.21 \\
\hline Sativene & 1391 & - & - & 0.37 & - \\
\hline Z-Jasmone & 1392 & - & 0.16 & 0.36 & - \\
\hline Methyl perillate & 1393 & - & 2.23 & - & - \\
\hline $\mathrm{n}$-Tetradecane & 1401 & - & - & 0.18 & - \\
\hline$\beta$-Longipinene & 1404 & - & 0.29 & 6.26 & - \\
\hline$\beta$-Isocomene & 1407 & - & 0.27 & & 0.18 \\
\hline E-Caryophyllene & 1415 & 0.36 & 6.33 & 0.25 & 0.51 \\
\hline$\alpha$-trans-Berganotene & 1431 & - & 0.97 & - & - \\
\hline$\alpha$-Guaiene & 1435 & - & 1.15 & 0.16 & - \\
\hline Epi- $\beta$-Santalene & 1444 & 0.1 & 1.77 & - & - \\
\hline $\mathrm{Z}$ - $\beta$-Farnesene & 1445 & - & $\cdot$ & - & 0.27 \\
\hline cis-Muurola-3,5-diene & 1450 & - & & 0.14 & \\
\hline$\alpha$-Himachalene & 1451 & 0.4 & 2.88 & & 0.79 \\
\hline$\alpha$-neo-Clovene & 1456 & 0.75 & 2.87 & 0.38 & - \\
\hline$\alpha$-Patxhoulene & 1457 & . & . & 0.62 & - \\
\hline Allo-aromadendrane & 1460 & - & 0.57 & 0.28 & - \\
\hline 9-Epi-(E)-Caryophyllene & 1470 & 0.1 & 0.19 & 0.19 & 2.11 \\
\hline$\beta$-Acoradiene & 1472 & 0.17 & 0.3 & 0.31 & - \\
\hline Drima-7,9(11)-diene & 1475 & 0.12 & 0.15 & & - \\
\hline trans-Cadina-1(6),4-diene & 1476 & - & 2.69 & 3.47 & - \\
\hline$\gamma$-Muurolene & 1481 & 2.67 & 1.96 & 0.81 & 0.3 \\
\hline Cabreuva oxide D & 1482 & - & - & 0.25 & - \\
\hline$\alpha$-Amorphene & 1485 & - & 0.59 & 0.23 & 0.1 \\
\hline Germactrene D & 1487 & 0.1 & 0.82 & 0.13 & - \\
\hline$\beta$-Selinene & 1491 & 3.76 & 6.02 & 1.45 & 0.49 \\
\hline$\delta$-Selinene & 1493 & - & - & 0.78 & 1.05 \\
\hline cis-Cadina-1,4-diene & 1496 & 0.63 & 0.39 & - & - \\
\hline$\alpha$-Muurolene & 1500 & - & - & - & 0.17 \\
\hline
\end{tabular}




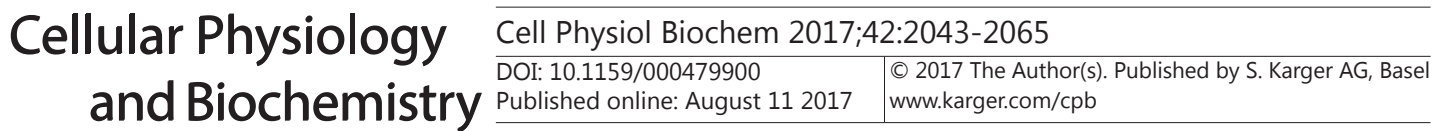

Saleh et al.: Anticancer Activity of $P$. Spinosa Essential Oils

$\mu \mathrm{g} / \mathrm{mL}$ (for F-PSEO) and $3.90 \pm$ $0.36 \mu \mathrm{g} / \mathrm{mL}$ (for L-PSEO), confirming the efficacy of both oils against cancer cells (Table 2).

The toxicity of F-PSEO and L-PSEO is mediated by apoptosis

Several reports have shown that the anti-proliferative activities of different essential oils towards various cancer cells are mediated by apoptosis [30-32]. To determine whether the cytotoxic effects of F-PSEO and L-PSEO are associated with induction of apoptosis, MCF-7 and MDA-MB-231 cells were treated with increasing concentrations of either oil and then analyzed by flow cytometry after staining with FITC-annexin-V/7-AAD. As shown in Fig. 3, both F-PSEO and L-PSEO induced a dose-dependent increase in the percentage of apoptotic MCF-7 (Fig. 3A) and MDA-MB-231 cancer cells (Fig. 3B). As observed with the viability results, F-PSEO triggered higher percentage of apoptosis in both cultured cells than L-PSEO. Quantitative measurement of the percentages of apoptosis in cultured cells pre-incubated for $48 \mathrm{~h}$ with 0.3 and $1.0 \mu \mathrm{g} / \mathrm{mL}$ of F-PSEO were $51.7 \pm 6.0 \%$ and $71.0 \pm 7.2 \%$ in MCF-7 cells (Fig. 3A) and $65.0 \pm$ $6.8 \%$ and $92.0 \pm 5.8 \%$ in MDAMB-231 cells (Fig. 3B), compared to $17.5 \pm 3.5 \%$ and 33.4 $\pm 5.4 \%$ (Fig. $3 \mathrm{~A}$ ) and $22.5 \pm$ $4.1 \%$ and $51.3 \pm 4.5 \%$ (Fig. $3 \mathrm{~B}$ ) when these cells were exposed to similar concentrations of

\begin{tabular}{|c|c|c|c|c|c|}
\hline \multirow[t]{2}{*}{ Compound } & \multirow[t]{2}{*}{$\mathrm{RRI}^{1}$} & \multicolumn{2}{|c|}{ F-PSEO (\%) } & \multicolumn{2}{|c|}{ L-PSEO (\%) } \\
\hline & & $\mathrm{H}-\mathrm{DST}^{2}$ & SPME & H-DST & SPME \\
\hline$\alpha$-Selinene & 1502 & - & - & 0.1 & \\
\hline Bicyclogermacrene & 1503 & 0.21 & 0.6 & - & - \\
\hline$\gamma$-Patchoulene & 1504 & - & - & - & . \\
\hline$(\mathrm{E}, \mathrm{E})-\alpha$-Farnesene & 1506 & - & 0.16 & - & - \\
\hline$\delta$-Amorphene & 1509 & 0.88 & 1.31 & - & - \\
\hline 10-epi-Italicene ether & 1510 & - & - & - & 0.1 \\
\hline$\gamma$-Cadinene & 1514 & 1.65 & 0.62 & 0.99 & 0.21 \\
\hline Cubebol & 1515 & 0.12 & & - & - \\
\hline Myristicin & 1519 & - & 0.14 & . & . \\
\hline Silphiperfolan-7-beta-ol & 1520 & 0.4 & 0.14 & - & - \\
\hline$\delta$-Cadinene & 1523 & 4.95 & - & 5.79 & - \\
\hline Zonarene & 1530 & 0.1 & . & 0.28 & - \\
\hline trans-Cadina-1(2),4-diene & 1533 & 0.14 & 0.19 & 0.1 & - \\
\hline$\alpha$-Cadinene & 1538 & - & 0.44 & - & - \\
\hline cis-Calamenene & 1540 & - & - & 0.41 & - \\
\hline$\alpha$-Calacorene & 1545 & - & - & 0.36 & - \\
\hline Selina -3,7(11)-diene & 1646 & - & - & 0.2 & - \\
\hline Silphiperfolan- $6-\beta$-ol & 1549 & - & - & 0.16 & - \\
\hline Elemol & 1550 & 0.91 & 1.39 & 0.39 & - \\
\hline Germacrene B & 1556 & - & - & 3.51 & - \\
\hline$\beta$-Calacorene & 1569 & - & - & 0.91 & - \\
\hline Germacrene-D-4-ol & 1579 & 4.28 & - & 3.01 & 0.1 \\
\hline Spathulenol & 1578 & - & - & 0.47 & - \\
\hline Globulol & 1583 & 0.1 & - & 0.1 & - \\
\hline cis- $\beta$-Elemenone & 1590 & $\cdot$ & - & $\cdot$ & 0.71 \\
\hline Viridiflorol & 1593 & 0.1 & . & . & - \\
\hline$\beta$-Oplopenone & 1603 & 0.35 & - & 0.81 & - \\
\hline$\beta$-atlantol & 1608 & - & - & 0.18 & - \\
\hline 1,10-di-epi-Cubenol & 1618 & 0.13 & - & 0.55 & 0.13 \\
\hline$\beta$-Cedrene epoxide & 1619 & - & - & 0.71 & - \\
\hline 10-epi-gamma-Eudesmol & 1624 & 0.2 & - & 0.75 & - \\
\hline$\gamma$-Eudesmol & 1631 & - & - & 0.11 & 3.83 \\
\hline$\alpha$-Muurolol & 1644 & 21.93 & - & 9.83 & 2.1 \\
\hline$\beta$-Eudesmol & 1648 & . & - & 4.47 & . \\
\hline$\delta$-Cadinol & 1650 & - & - & 1.69 & 1.45 \\
\hline$\alpha$-Cadinol & 1653 & 8.54 & - & 13.15 & 0.97 \\
\hline Selin-11-en-4-alpha-ol & 1661 & - & - & - & 3.17 \\
\hline Intermedeol & 1671 & 0.1 & - & - & $\cdot$ \\
\hline Cadalene & 1676 & - & - & 0.24 & - \\
\hline Khusinol & 1678 & - & - & 0.21 & - \\
\hline Occidentalol acetate & 1681 & - & - & 0.1 & - \\
\hline Acorenone B & 1699 & 33.85 & - & 9.64 & 0.1 \\
\hline Eudesm-7(11)-en-4-ol & 1704 & - & - & 0.74 & - \\
\hline Longifolol & 1712 & - & - & 0.7 & - \\
\hline Guaiol acetate & 1722 & 0.18 & - & & 1.09 \\
\hline z- Nuciferol & 1726 & $\cdot$ & - & 0.14 & \\
\hline (2E,6Z)-Farnesol & 1745 & - & - & - & 0.22 \\
\hline 14-0xy-alpha-Muurolene & 1771 & 0.22 & - & - & 0.1 \\
\hline 2-Hexyl-Z-cinnamaldehyde & 1774 & - & - & 1.75 & \\
\hline 14-Hydroxy-alpha-Muurolene & 1780 & - & - & & 0.1 \\
\hline Hinesol acetate & 1783 & - & - & 0.52 & 3.35 \\
\hline n-Octadecane & 1802 & - & - & 0.1 & - \\
\hline Nootkatone & 1805 & - & - & 0.27 & - \\
\hline Drimenone & 1809 & - & - & & 0.24 \\
\hline Khusinol acetate & 1827 & - & - & & 0.71 \\
\hline (2E,6E)-Farnesyl acetate & 1839 & - & - & 0.27 & 0.38 \\
\hline Oplopanonyl acetate & 1883 & 7.22 & - & 0.79 & - \\
\hline Beta-chenopodiol-6-acetate & 1891 & - & - & 0.73 & - \\
\hline Phytol & 1927 & . & - & 0.11 & 3.38 \\
\hline Total & & 99.77 & 97.6 & 98.69 & 98.42 \\
\hline \multicolumn{6}{|c|}{ Classes of the identified compounds: } \\
\hline Monoterpenoids Hydrocarbons & & 3.07 & 44.09 & 0.57 & 22.27 \\
\hline Oxygenated Monoterpenoids & & 0.71 & 8.82 & 6.66 & 10.61 \\
\hline Sesquiterpene Hydrocarbons & & 17.76 & 38.64 & 34.06 & 34.15 \\
\hline Oxygenated Sesquiterpenoids & & 78.63 & 1.53 & 51.6 & 15.5 \\
\hline Oxygenated Diterpene & & - & - & 0.11 & 3.38 \\
\hline Aliphatic Compounds & & 0.1 & 4.38 & 2.16 & 10.39 \\
\hline Aromatic Compounds & & - & 0.14 & 2.32 & 2.12 \\
\hline
\end{tabular}

L-PSEO, respectively. These results also indicated that MDA-MB-231 cells are more sensitive to the treatment with either oil, than MCF-7 cells, and therefore these data are in agreement with those obtained testing the cell viability. Interestingly, there was only a slight marginal variation in the percentages of necrotic cells (annexin- $\mathrm{V}^{-} / 7 \mathrm{AAD}^{+}$) after exposure to the different concentrations of the essential oils, suggesting that most of the cytotoxic effects of F-PSEO and L-PSEO are mediated by apoptosis. Our finding that inhibition of necrosis by necrostatin-1 did not affect the percentages of dead cells caused by F-PSEO or L-PSEO suggesting that most of the cytotoxic activities of F-PSEO and L-PSEO are mediated by apoptosis 


\section{Cellular Physiology Cell Physiol Biochem 2017;42:2043-2065 \begin{tabular}{ll|l}
\hline and Bor 10.1159/000479900 & 2017 The Author(s). Published by S. Karger AG, Basel \\
\hline
\end{tabular}

Fig. 2. Low doses of P. spinosa essential oils inhibit the growth of breast cancer cell lines in a concentration-dependent manner. (A) MCF7, (B) MDA-MB-231 breast adenocarcinoma cells and (C) immortalized non-cancerous MCF-10-2A breast epithelial cells were treated with increasing concentrations of F-PSEO and L-PSEO (0.1 to $10.0 \mu \mathrm{g} / \mathrm{mL}$ ), or doxorubicin (1.0 to $10.0 \mu \mathrm{g} / \mathrm{mL}$ ) for $48 \mathrm{~h}$ as indicated in each graph. The percentage of cell viability in each sample was compared to untreated control containing the carrier solvent DMSO. The sigmoidal curves shown were obtained by plotting the mean percentages of viability versus the logarithmic concentrations of the oil in $\mathrm{g} / \mathrm{mL}$, and the $\mathrm{IC}_{50}$ value was determined using a non-linear regression analysis of GraphPad Prism 6 software. The results shown represent the mean \pm SD of three independent experiments. The hash sign (\#) was used for values that are significantly different and the astrix $\left({ }^{*}\right)$ for statistically insignificant values as compared to untreated control.
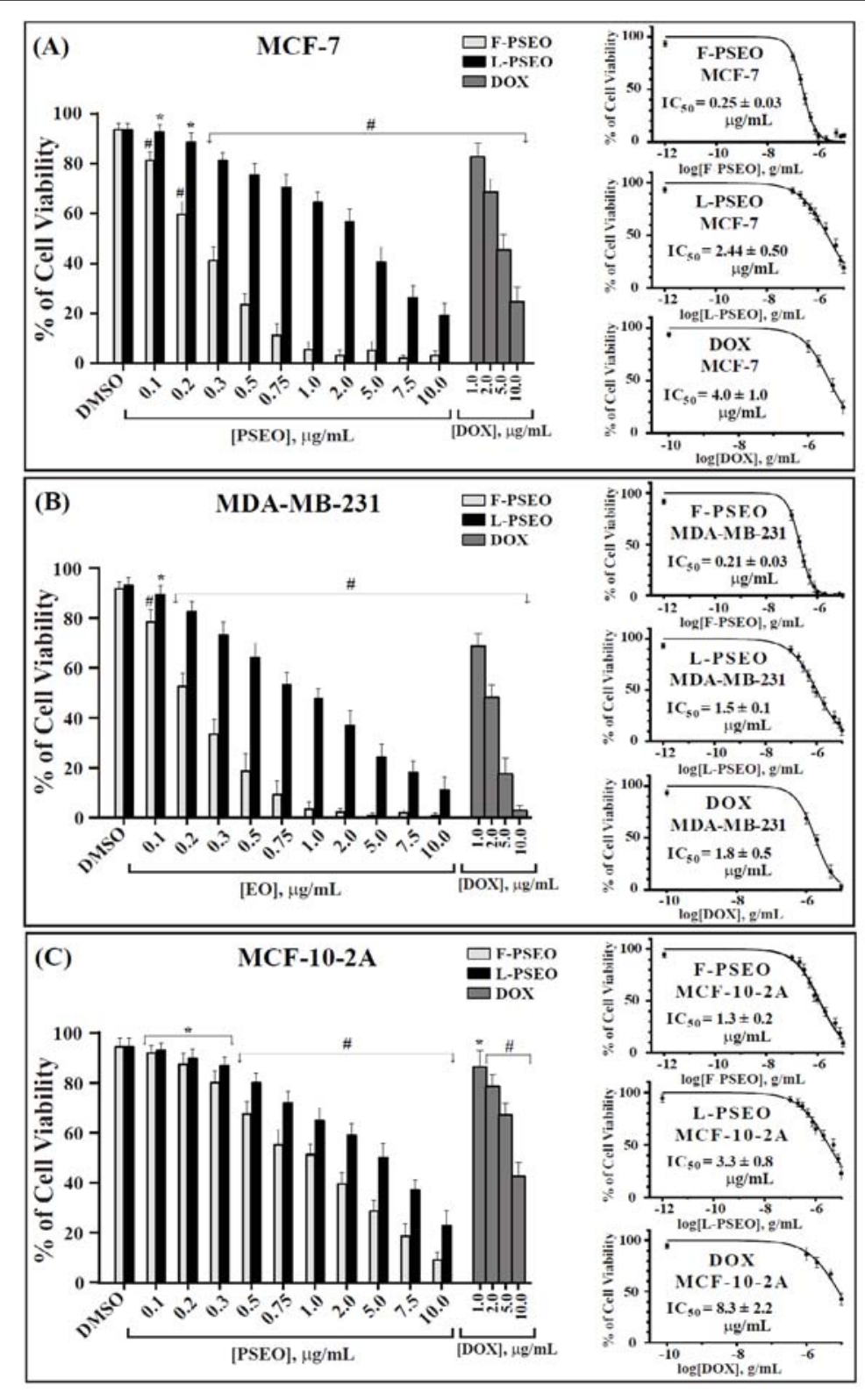

Table 2. The cytotoxicity of $P$. spinosa against different hematological cancer cells and normal PB-MNCs. ${ }^{*}$ Results are expressed as the mean of $\mathrm{IC}_{50} \pm \mathrm{SD}$ of three independent experiments. The $\mathrm{IC}_{50}$ value was determined using a non-linear regression analysis of GraphPad Prism 6 software as described in Fig. 2

\begin{tabular}{lcc}
\hline Cell Line & $\begin{array}{c}\text { F-PSEO } \\
\text { 'IC } 50(\mu \mathrm{g} / \mathrm{mL})\end{array}$ & $\begin{array}{c}\text { L-PSEO } \\
{ }^{\mathrm{I}} \mathrm{C}_{50}(\mu \mathrm{g} / \mathrm{mL})\end{array}$ \\
\hline MV4-11 & $0.09 \pm 0.02$ & $0.22 \pm 0.05$ \\
HL-60 & $0.13 \pm 0.06$ & $0.35 \pm 0.09$ \\
K562 & $0.18 \pm 0.07$ & $0.67 \pm 0.12$ \\
Jurkat & $0.22 \pm 0.07$ & $0.52 \pm 0.10$ \\
THP-1 & $0.24 \pm 0.11$ & $0.83 \pm 0.16$ \\
U937 & $0.33 \pm 0.08$ & $1.27 \pm 0.31$ \\
PB-MNCs & $2.8 \pm 0.45$ & $3.9 \pm 0.36$ \\
\hline
\end{tabular}

(data not shown). Most of the cytotoxicity of the oils in the hematological cell lines were also due to apoptosis (not shown).

\section{Morphological changes induced by F-PSEO and L-PSEO in breast cancer cells}

In addition to the increase in the number of annexin- $\mathrm{V}^{\text {tve }}$ cells, treatment with the oils was associated with typical morphological changes of apoptotic cells. Both F-PSEO and L-PSEO promoted cellular shrinkage, loss of shape, detachment from adhering surface and condensation/ fragmentation of nuclei in MCF-7 and MDA-MB-231 cultured cells (Fig. 4A 
 \begin{tabular}{ll|l|l|l|}
\hline and Bor 10.1159/000479900 & 2017 The Author(s). Published by S. Karger AG, Basel \\
\hline
\end{tabular}

Fig. 3. The cytotoxic effects of P. spinosa essential oils against breast cancer cells are mediated by apoptosis. (A) MCF-7 and (B) MDAMB-231 cells were treated with increasing concentrations of F-PSEO and L-PSEO (0.1 to $5.0 \mu \mathrm{g} / \mathrm{mL}$ ) or with $5.0 \mu \mathrm{g} / \mathrm{mL}$ doxorubicin for 48 $\mathrm{h}$ and apoptosis was analyzed by a flow cytometer after staining with FITC-annexin-V/7-AAD. The graphs shown represent the summary mean percentages \pm SD of apoptosis (early and late apoptosis) of three independent experiments. The scattered flow cytometry blots showing the percentages of early and late apoptosis are indicated for one representative experiment. (\#) for values that are significantly different and $\left(^{*}\right.$ ) for statistically insignificant values as compared to untreated control.

and $4 \mathrm{~B}$ ). These changes were not affected by incubating the cells with necrostatin-1 prior to addition of the oils, supporting the fact that they were triggered by apoptosis rather than necrosis (data not shown).

Role of caspases in F-PSEOand L-PSEO-induced apoptosis

Execution of cellular apop-
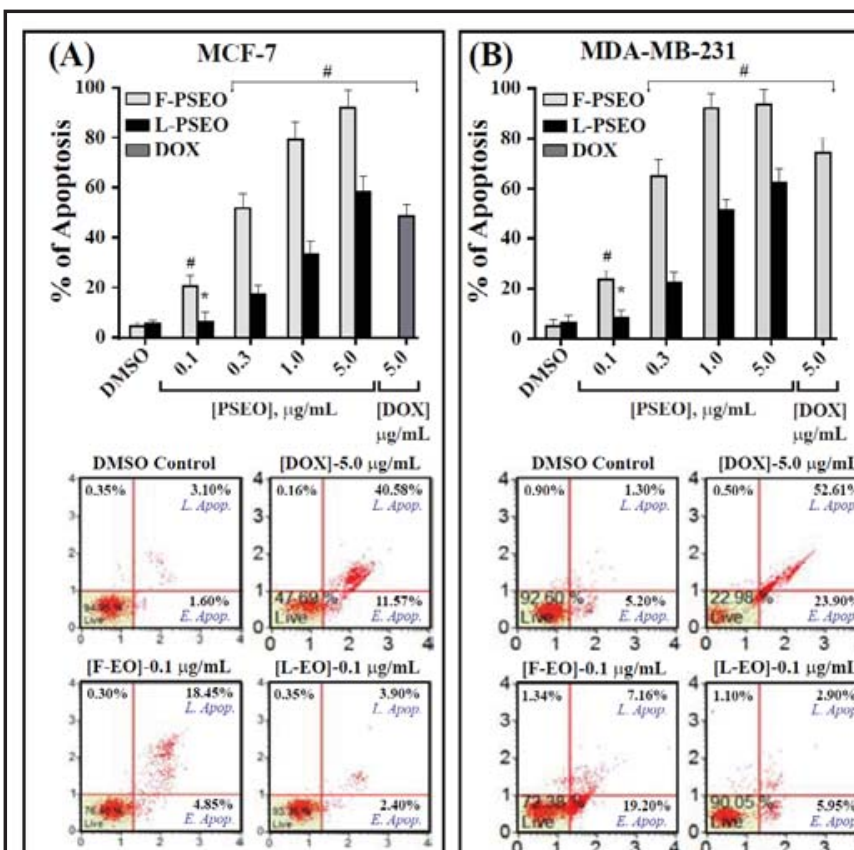

[F-EO]-0.3 $\mu \mathrm{g} / \mathrm{mL}$
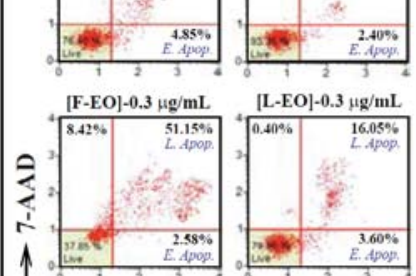

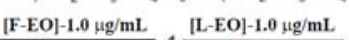
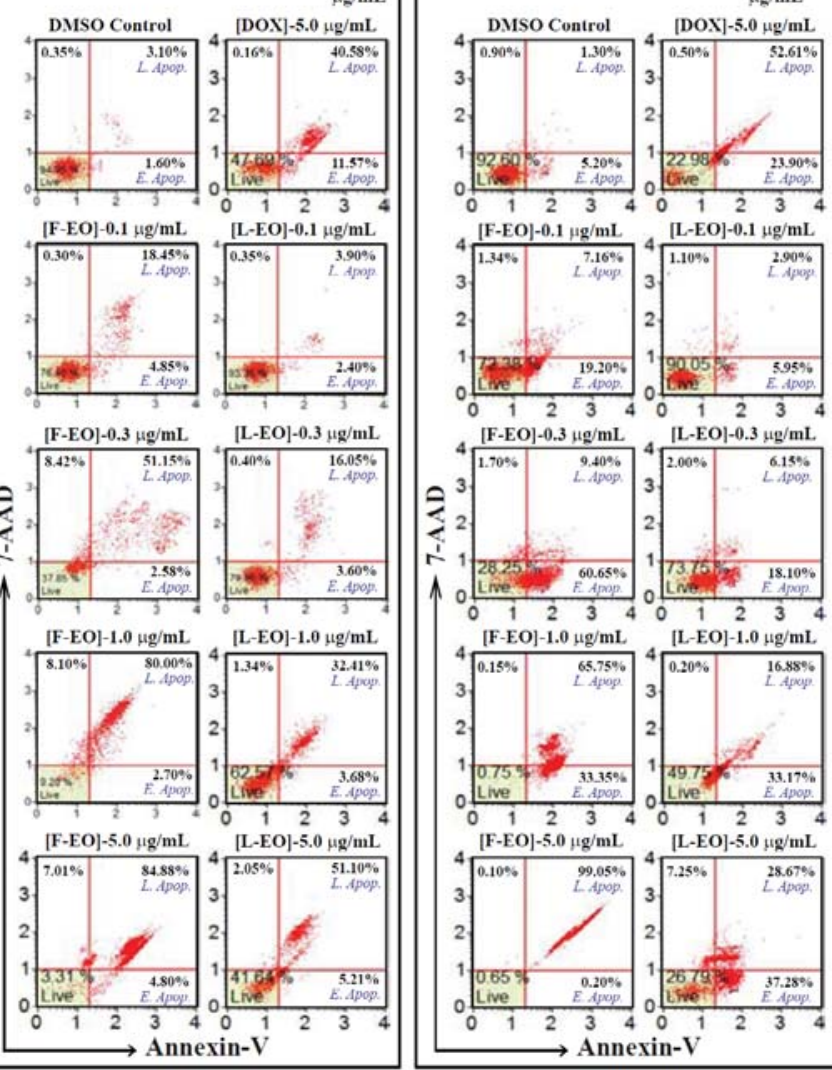

tosis induced by cytotoxic agents including plant extracts requires activation of terminal/ executioner caspases, mainly caspase- 3 and -7 , which are critical for cleaving/inactivation of specific key regulatory proteins [33]. To evaluate the involvement of caspase activation in the essential oil-induced apoptosis, we examined whether treatments with various concentrations of F-PSEO and L-PSEO lead to processing and subsequent activations of caspase-3 in MCF-7 and MDA-MB-232 cells. Processing of caspase-3 was analyzed by Western blotting (Fig. 4C and 4D) and its enzymatic activation, along with caspase-7, by colorimetric assays (Fig.4E and 4F) of lysates obtained from the treated cells. As shown in Fig. 4C and 4D, a dose-dependent processing of caspase- 3 was detected by the increased intensity of its p19 cleaved form band after exposure of MCF-7 and MDA-MB-231cells to increasing concentrations of both oils, with maximum levels occurring after exposure to $5.0 \mu \mathrm{g} / \mathrm{mL}$ of F-PSEO and L-PSEO. Processing of caspase-3 paralleled the cleavage of its main substrate PARP. Similar to p19 of caspase-3, the cleaved band of PARP (p97) appeared after treating both cells with $0.1 \mu \mathrm{g} / \mathrm{mL}$ of F-PSEO, while it was only detected after exposing the cells to $0.3 \mu \mathrm{g} / \mathrm{mL}$ of L-PSEO (Fig. 4C and 4D). Thus, processing of caspase-3 and cleavage of PARP coincided with the demonstrated dose-dependent increase in apoptotic cells (Fig. 3) and their morphological changes shown in Fig. 4A and 4B. 

Cellular Physiology Cell Physiol Biochem 2017;42:2043-2065

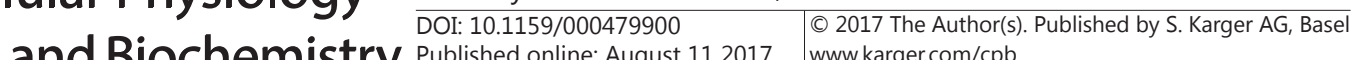 and Biochemistry Publisned onIne: August 112017 www.karger.com/cpb

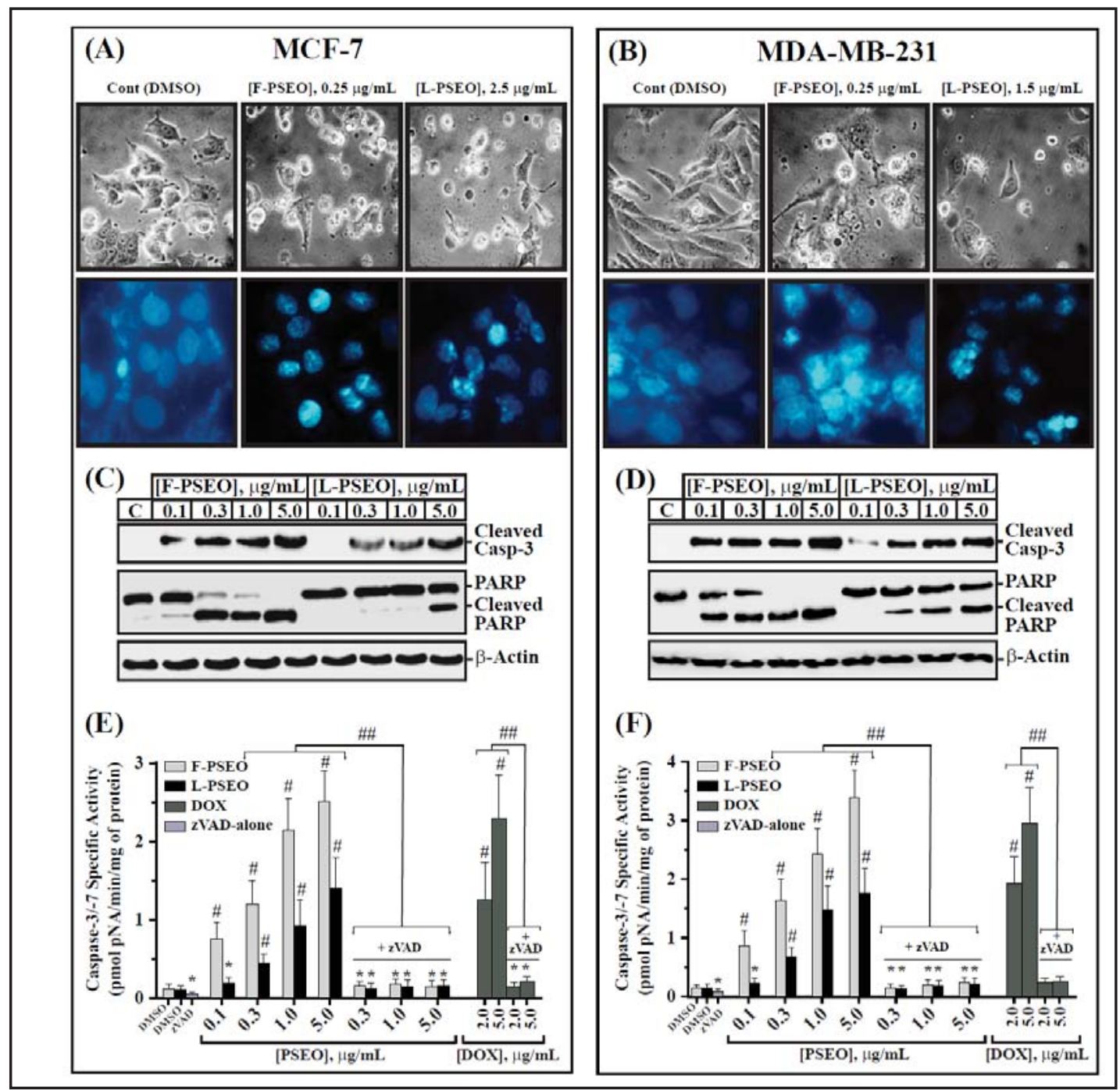

Fig. 4. P. spinosa essential oils trigger apoptosis morphological changes and activation of executioner caspases in breast cancer cells. (A) MCF-7 cells were treated with $0.3 \mu \mathrm{g} / \mathrm{mL}$ of F-PSEO or $2.5 \mu \mathrm{g} / \mathrm{mL}$ of L-PSEO and (B) MDA-MB-231 cells with $0.3 \mu \mathrm{g} / \mathrm{mL}$ of F-PSEO or $1.5 \mu \mathrm{g} / \mathrm{mL}$ of L-PSEO for $48 \mathrm{~h}$ as indicated on top of each photograph. The cells were photographed before fixation and after staining with Hoechst 33342 . The photographs show the morphological changes of unstained cells, and the condensation of chromatin material and fragmentation of nuclei in apoptotic stained cells. (C \& D) Western blot analysis showing cleaved form of processed caspase- 3 and PARP cleavage in lysates $(35 \mu \mathrm{g})$ from both cell lines treated with various concentrations of F-PSEO and L-PSEO as indicated on top of each lane. The accurate molecular size of the shown bands was verified by running pre-stained molecular weight standards with each gel. The same membranes were also probed with an antibody against $\beta$-actin as loading controls. (E \& F) Extracts (20 $\mu$ g proteins) from MCF-7 and MDA-MB-231 cells treated with different concentrations of F-PSEO, L-PSEO or doxorubicin for $48 \mathrm{~h}$ were analyzed for caspase-3/-7 catalytic activities using their specific colorimetric tetrapeptide substrate. The specific enzyme activities, which represent the mean \pm SD of three independent experiments, were measured as described in the methods. The cells were also treated with $60 \mu \mathrm{M}$ of the general caspase inhibitor z-VAD-FMK for $4 \mathrm{~h}$ prior to addition of the essential oils or doxorubicin as negative controls. (\#) for results that are significantly different and $(*)$ for statistically insignificant values as compared to untreated control.

Detection of the cleaved form of caspase-3 paralleled its activation. As illustrated in Fig. $4 \mathrm{E}$ and $4 \mathrm{~F}, 0.1 \mu \mathrm{g} / \mathrm{mL}$ of F-PSEO triggered a significant activation of caspase-3/-7 in both MCF-7 and MDA-MB-231cells, while this activity appeared after treating the cells with 0.3 


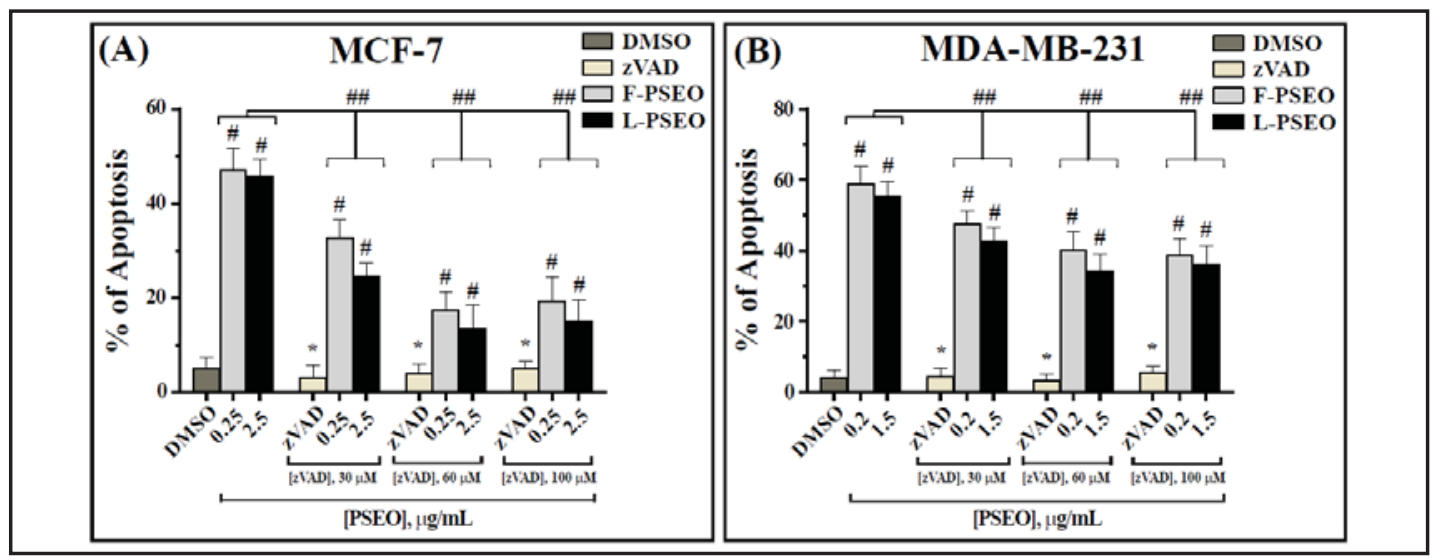

Fig. 5. P. spinosa essential oils-induced apoptosis is partially dependent on caspases activation. (A) MCF-7 and (B) MDA-MB-231 cells were exposed to $0.25 \mu \mathrm{g} / \mathrm{mL}$ and $0.20 \mu \mathrm{g} / \mathrm{mL}$ of F-PSEO or $2.5 \mu \mathrm{g} / \mathrm{mL}$ and $1.5 \mu \mathrm{g} /$ $\mathrm{mL}$ of L-PSEO, respectively, in the presence and absence of increasing concentrations of z-VAD-FMK (30 to $100 \mu \mathrm{M}$ ) for $48 \mathrm{~h}$. Subsequently, apoptosis was analyzed after staining with FITC-annexin-V/7AAD as described in Fig. 3. The graphs shown represent the summary of mean percentages \pm SD of apoptosis (early and late apoptosis) of three independent experiments. (\#) sign, for results that are significantly different and $\left({ }^{*}\right)$ for statistically insignificant values as compared to untreated DMSO control. The double hash sign (\#\#) was used for values that are significantly different from the oil-treated cells in the absence of z-VAD-FMK.

$\mu \mathrm{g} / \mathrm{mL}$ of L-PSEO. F-PSEO-induced activation of caspase-3/-7 which reached a mean peak values of $2.52 \pm 0.40$ and $3.39 \pm 0.47 \mathrm{pmol} \mathrm{pNA} / \mathrm{min} / \mathrm{mg}$ protein after incubating MCF- 7 and MDA-MB-23 cells with $5.0 \mu \mathrm{g} / \mathrm{mL}$ of the oil, respectively. In contrast, this activity reached only $1.40 \pm 0.4$ and $1.76 \pm 0.43 \mathrm{pmol} \mathrm{pNA} / \mathrm{min} / \mathrm{mg}$ protein after exposing MCF-7 and MDAMB-23 cells to $5.0 \mu \mathrm{g} / \mathrm{mL}$ of L-PSEO, respectively. In all the tested doses against both cell lines, F-PSEO was able to induce approximately 1.5 to 2.5 -fold more activation of caspase-3/-7 than L-PSEO. Again, these results support the findings in Fig. 2 and Fig. 3 that F-PSEO is more toxic to cancer cells than L-PSEO. Under similar conditions, $5.0 \mu \mathrm{g} / \mathrm{mL}$ of doxorubicin triggered a specific caspase-3/-7 activity of $2.30 \pm 0.55 \mathrm{pmol} \mathrm{pNA} / \mathrm{min} / \mathrm{mg}$ protein in MCF-7 cells and $2.95 \pm 0.61 \mathrm{pmol} \mathrm{pNA} / \mathrm{min} / \mathrm{mg}$ protein in MDA-MB-231 cells, suggesting that both F-PSEO and L-PSEO are comparatively potent inducers of caspase-dependent apoptosis in these cells. The specificity of the detected caspase activity was confirmed by its absence when the cells were pre-incubated with the general caspase inhibitor z-VAD-FMK prior to the addition of the different concentrations of either oil. Furthermore, both oils demonstrated a timedependent activation of caspase-3/7 in MCF-7 and MDA-MB-231 cells, reaching a maximum activity between 32 and $37 \mathrm{~h}$ of incubation (data not shown).

To evaluate the role of caspase activation in the oil-induced apoptosis, MCF-7 and MDA-MB-231 cells were incubated for $6 \mathrm{~h}$ with increasing concentrations of z-VAD-FMK (30-100 $\mu \mathrm{M})$ prior to exposure to a single dose of either F-PSEO $(0.25 \mu \mathrm{g} / \mathrm{mL}$ and $0.20 \mu \mathrm{g} /$ $\mathrm{mL})$ or L-PSEO $(2.5 \mu \mathrm{g} / \mathrm{mL}$ and $1.5 \mu \mathrm{g} / \mathrm{mL})$, corresponding to their approximate $\mathrm{IC}_{50}$ in both cell lines, respectively. Subsequently, apoptosis in these samples was analyzed by a flow cytometer after staining with FITC-annexin-V/7AAD. In comparison to MCF-7 cells treated with F-PSEO or L-PSEO alone (Fig. 5A), z-VAD-FMK significantly decreased the oil-induced apoptosis from $47.2 \pm 4.5 \%$ and $45.8 \pm 3.5 \%$ to $32.6 \pm 4.1 \%$ and $24.5 \pm 3.0 \%$ (with $30.0 \mu \mathrm{M}$ z-VAD-FMK, corresponding to $\sim 30 \%$ and $\sim 47 \%$ inhibition, respectively), and to $17.3 \pm 4.0 \%$ and $13.6 \pm 4.8 \%$ (with $60.0 \mu \mathrm{M}$ z-VAD-FMK, corresponding to $\sim 63 \%$ and $\sim 70 \%$ inhibition, respectively). Importantly, the presence of $60.0 \mu \mathrm{M}$ of z-VAD-FMK was adequate to completely inhibit the F-PSEO- and L-PSEO-induced activation of the effector caspases illustrated in Fig. 4A. Therefore, further increase in the concentration of z-VAD-FMK to $100 \mu \mathrm{M}$ did not show additional apoptosis recovery effects in MCF-7 cells (Fig. 5A). These data suggest that the ability of both oils to promote MCF-7 cell death is highly, but not completely, dependent on caspase activation. On the other hand, z-VAD-FMK was less effective in reversing the 

Cellular Physiology Cell Physiol Biochem 2017;42:2043-2065

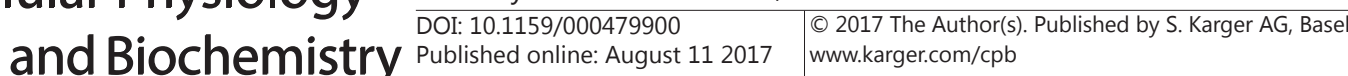

Fig. 6. P. spinosa essential oils modulate the expression of anti-apoptotic and pro-apoptotic members of the Bcl-2 family. (A) 35 $\mu \mathrm{g}$ protein lysates from MCF-7 and (B) MDA-MB-231 cells treated with varying concentrations of F-PSEO or L-PSEO were immunoblotted with specific antibodies against Bcl-2, Bcl- $\mathrm{X}_{\mathrm{L}^{\prime}}$ Bax, Bak and $\beta$-actin as labeled on each blot. The identity of the shown bands was verified by comparing its corresponding molecular weight to prestained molecular weight standards ran on each gel. (C \& D) Densitometric scanning for the intensity levels of

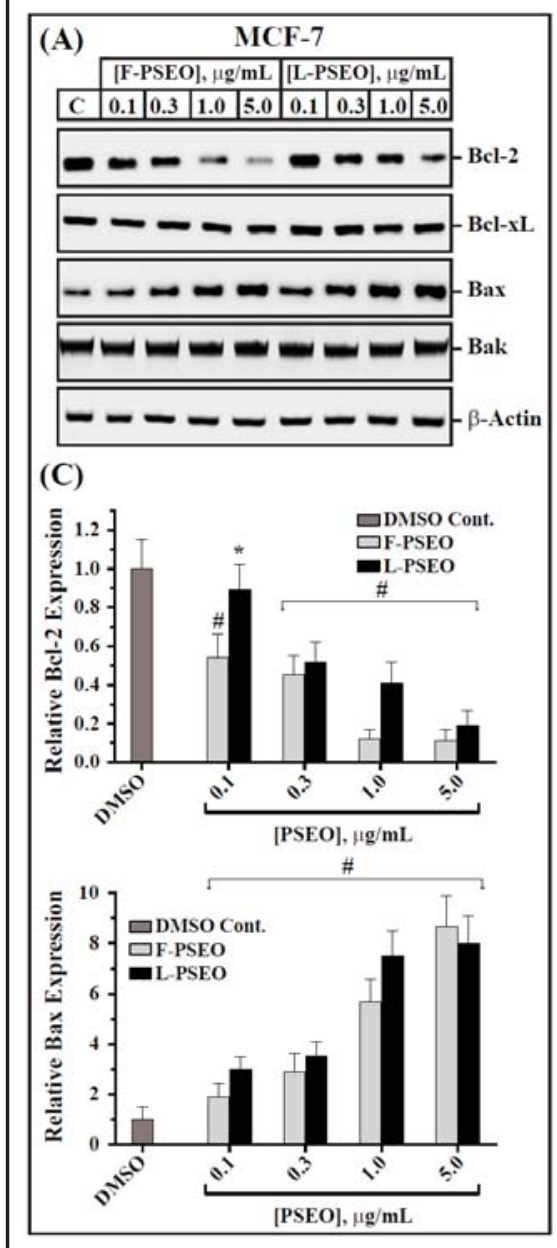

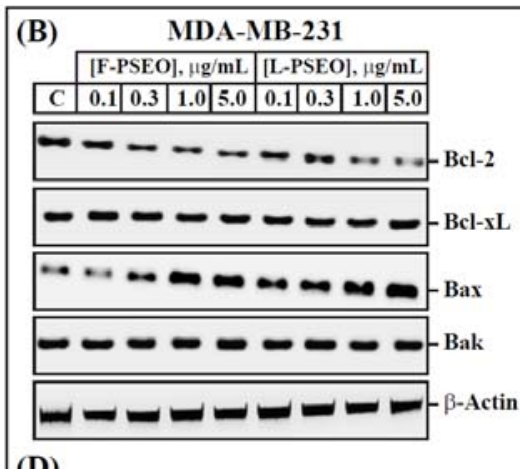

(D)
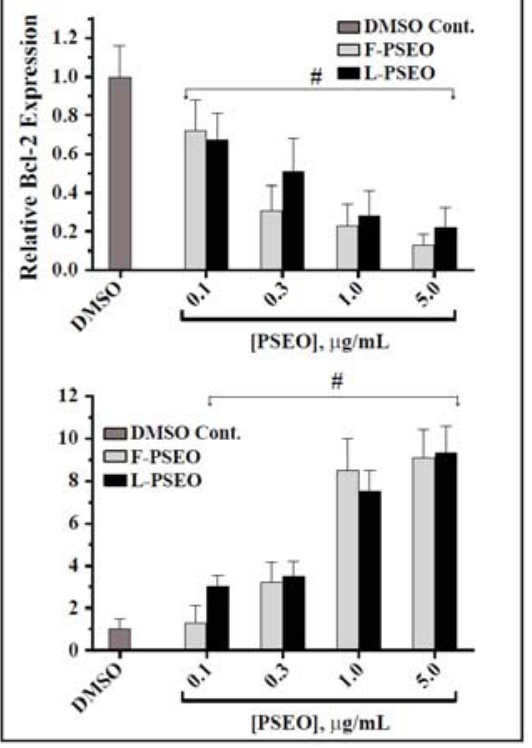

Bcl-2 and Bax (relative to untreated control), obtained from Western blotting of the protein in both cell lines treated with different concentrations of the oils for $48 \mathrm{~h}$. The values represent the mean relative band densities \pm SD of two independent experiments.

apoptotic effect of F-PSEO and L-PSEO in MDA-MB-231 (Fig. 5B). Pre-incubating cells with $60 \pm \mathrm{M}$ z-VAD-FMK caused $\sim 32 \%$ (from $58.8 \pm 5.1 \%$ to $40.2 \pm 5.1 \%$ ) and $38 \%$ (from $55.4 \pm$ $4.0 \%$ to $34.3 \pm 4.7 \%$ ) suppression of apoptosis induced by F-PSEO and L-PSEO, respectively in the absence of the general caspase inhibitor (Fig. 5B). Thus, the results indicated that the oil induced apoptosis in MDA-MB-231 is partially dependent on caspase activation.

\section{F-PSEP and L-PSEO alter the expression of Bcl-2 and Bax in breast cancer cells}

The pro- and anti-apoptotic Bcl-2 family members play a critical role in apoptosis by regulating the translocation of cytochrome $\mathrm{c}$ into the cytoplasm to trigger activation of the APAF-1/caspase-9 apoptosome [34]. Our immunoblotting results in Fig. 6 showed that exposure of MCF-7 and MDA-MB-231 to the oils decreased the expression levels of the antiapoptotic protein Bcl-2 and increased the expression of the proapoptotic factor Bax, while the amount of the proapoptotic protein Bak and antiapoptotic Bcl- $\mathrm{X}_{\mathrm{L}}$ remain unchanged (Fig. $6 \mathrm{~A}$ and $6 \mathrm{~B}$ ). Quantification of Bcl-2 revealed that the protein levels gradually decreased with increasing concentrations of the oil, and reached $\sim 11$-fold and $\sim 5$-fold less than the amount in untreated control after exposure of MCF-7 cells to $5.0 \mu \mathrm{g} / \mathrm{mL}$ of F-PSEO and L-PSEO (Fig. 6C), while the relative amounts of Bax were elevated to $\sim 9$-fold and $\sim 8$-fold over the control after treatment with an identical concentration of these oils, respectively. Similarly, the protein levels of Bcl-2 were reduced $\sim 8$-fold and $\sim 5$-fold, and Bax increased $\sim 9$-fold as compared to 


\section{Cellular Physiology \\ Cell Physiol Biochem 2017;42:2043-2065 and Biochemistry

Fig. 7. F-PSEO and L-PSEO induce a dose-dependent cell cycle arrest at G0/G1 phase in MCF-7 and MDA-MB-231cells. (A \& B) MCF-7 and (C \& D) MDAMB-231 cells were treated with DMSO $(0.1 \%$, control) or increasing concentrations $(0.1$ to 5.0 $\mu \mathrm{g} / \mathrm{mL}$ ) of F-PSEO (A \& C) and L-PSEO (B \& D) for $24 \mathrm{~h}$, and cell cycle analysis was performed as described under the methods. Data shown are representative of three independent experiments. The bar graphs show the mean \pm SD of the three independent experiments. The DNA content analysis by flow cytometry is shown for one representative experiment. (\#) sign for results that are significantly different and $(*)$ for statistically insignificant values as compared to untreated control.

the protein bands intensity in untreated MDA-MB-231 cells after incubation with $5.0 \mu \mathrm{g} / \mathrm{mL}$ of the respective oils (Fig. 6D). These results strongly suggest that the oilinduced apoptosis involves mitochondrial pathway of apoptosis.
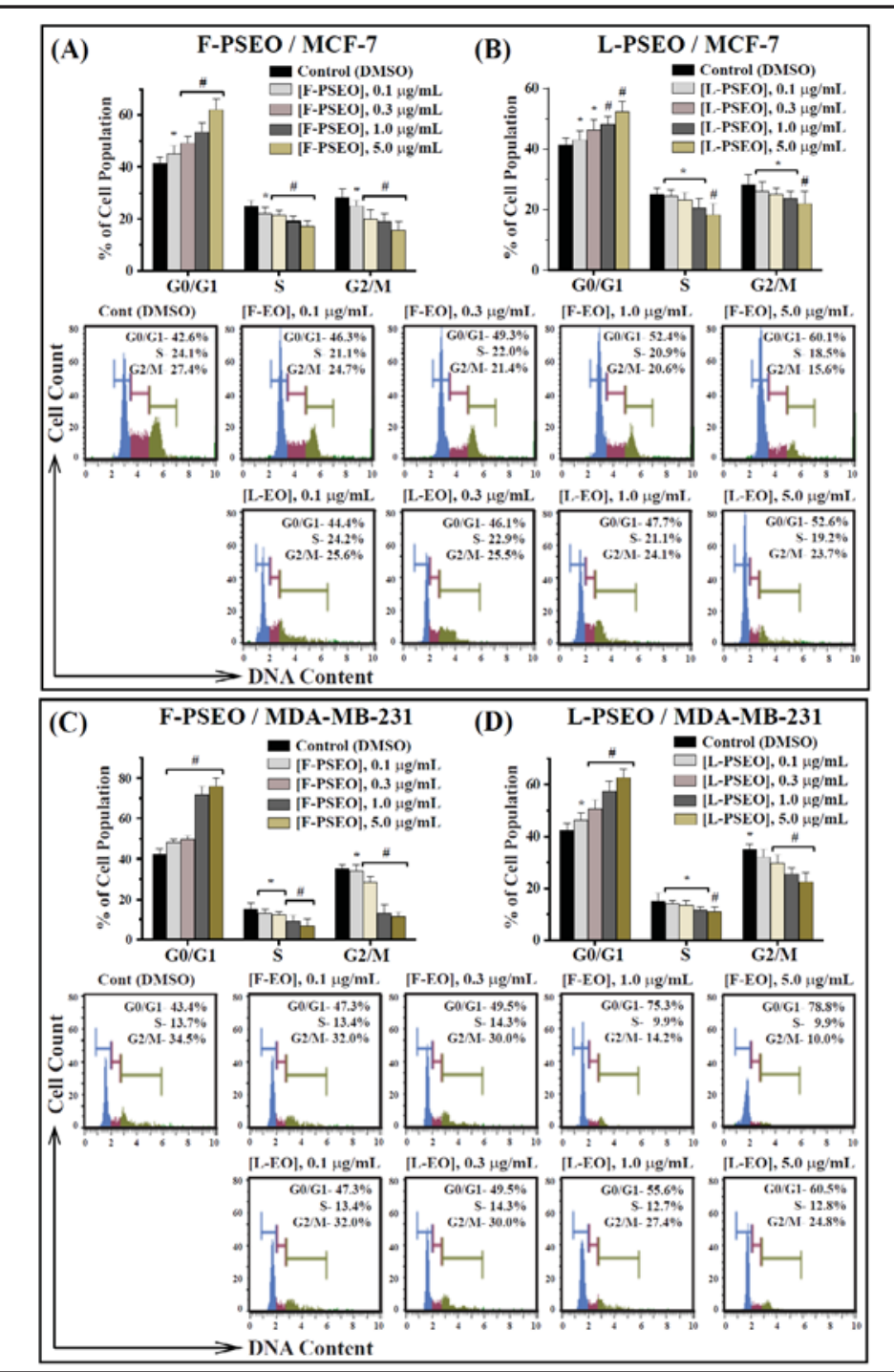

F-PSEO and L-PSEO induce cell cycle arrest in the GO/G1 phase by modulating the expression of regulatory proteins

Several plant essential oils have been documented to arrest cell cycle leading to tumor cell death $[35,36]$. When MCF-7 and MDA-MB-231 cells were treated with increasing concentrations of F-PSEO and L-PSEO for $24 \mathrm{~h}$, a dose dependent cell cycle arrest at G0/G1 phase was evident with concomitant decrease in the $S$ and G2/M phases (Fig. 7). However, MDA-MB-231 cells were more susceptible to oil-induced inhibition of cell cycle progression from G1 to S phase than MCF-7 cells. While the percentage of MCF-7 cell population in G0/ G1 phase increased from $41.30 \pm 2.30 \%$ in the absence of the oil to $62.10 \pm 4.2 \%$ and $52.3 \pm$ $3.6 \%$ in the presence of $5.0 \mu \mathrm{g} / \mathrm{mL}$ of F-PSEO (Fig. 7A) and L-PSEO (Fig. 7B), respectively, the increase of the same population in MDA-MB-231 was from $42.4 \pm 2.6 \%$ (untreated control) to $76.0 \pm 4.0 \%$ (Fig. 7C) and $62.6 \pm 3.4 \%$ (Fig. 7D) after treatment with the exact concentration of the respective oils. S-phase cells showed slightly significant decrease, after exposure to $5.0 \mu \mathrm{g} / \mathrm{mL}$ of either oil, but the G2/M cell population dramatically decreased from $35.0 \pm$ $2.1 \%$ to $11.4 \pm 2.4 \%$ ( $\sim 67 \%$ reduction) and $22.5 \pm 3.5 \%$ ( $\sim 36 \%$ reduction) in MDA-MB-231 treated with F-PSEO and L-PSEO, respectively (Fig. 7C and 7D). In contrast, this population was only decreased from $28.2 \pm 3.3 \%$ to $15.6 \pm 3.5 \%$ ( $\sim 45 \%$ reduction, Fig. $7 \mathrm{~A})$ and $22.0 \pm$ $4.0 \%(\sim 22 \%$ decrease, Fig. 7B) after the exposure of MCF-7 cells to a similar concentration of F-PSEO and L-PSEO, respectively. 
Fig. 8. F-PSEO and L-PSEO modulate the expression of Cyclin D1, CDK4 and p21 in the invasive hormone insensitive breast cancer cell line MDA-MB-231. The cells were treated with $0.1 \%$ DMSO (control) or increased concentrations of F-PSEO and L-PSEO (0.1 to $5.0 \mu \mathrm{g} / \mathrm{mL})$ for $24 \mathrm{~h}$, then $35 \mu \mathrm{g}$ proteins were analyzed by Western blotting with antibodies against different cyclins (D1, D2, D3 and E), CDKs (2, 4, and 6) and CKI (p21, p27) as labeled on each blot. The immunoblots shown are representations of two independent experiments. The identity of the shown bands was verified by comparing its corresponding molecular weight to pre-stained molecular weight standards ran on each gel. The same membranes were also probed with an antibody against $\beta$-actin as loading controls.

Since changes in cell population at different stages was more prominent in MDA-MB-231 treated cells, we analyzed whether these effects were accompanied by alteration in the level of G1 to S transition-regulatory factors. We observed that cyclin D1 along with the cyclin dependent kinase CDK4 were decreased in a

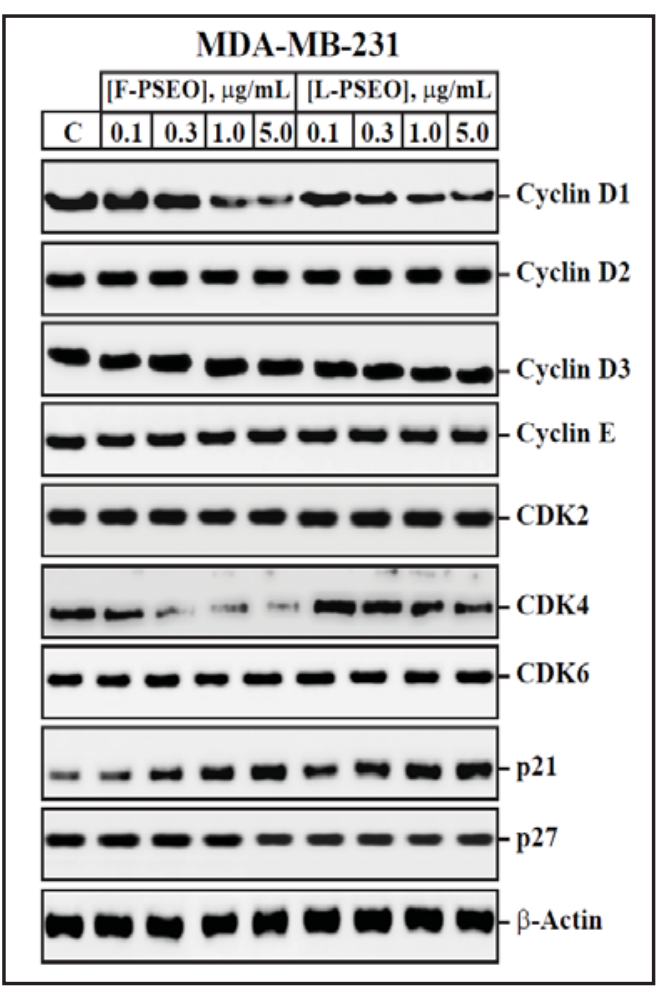
dose dependent fashion of the oil, but cyclin D2, cyclin D3, cyclin E, CDK2 and CDK6 were not significantly affected by F-PSEO and L-PSEO treatment (Fig. 8). Expression of the CKI was modulated as exhibited by an increase in p21 level but keeping p27 unchanged (Fig. 8).

\section{Discussion}

Each year, more than 1.3 million women worldwide are diagnosed with breast carcinomas. This disease is the leading cause of cancer among women in the developed countries, accounting for about $14 \%$ of cancer related deaths and the figures continue to increase. Although the current anticancer drugs continue to play a major role in breast cancer treatment, there are still several subtypes of breast cancer that do not respond effectively to the available therapeutic strategies. Hence, there is an impetus to identify, test and develop more effective treatments [1,2]. In the current study, we aim to analyze the chemical composition, cytotoxicity and possible modes of action of the essential oil extracted from Pallines spinosa flowers and leaves in two different breast tumor cell lines MCF-7 and MDAMB-231which have two distinct genetic backgrounds that represent most of the reported human mammary carcinomas.

In the last two decades, there has been a substantial focus on natural plant components with potential anticancer activities aiming to develop novel chemotherapeutic agents for cancer $[37,38]$. In fact, a substantial number of clinically active drugs that are used in cancer therapy are either natural products or based on natural products, including vinblastine, vincristine, etoposide, teniposide, paclitaxel, doxetaxel, and camptothecin [37]. In line with these studies, we have developed a dedicated research program to identify and characterize components of plants extracts possessing strong anti-proliferative activities. Therefore, the aim of the present study was to identify components of essential oils extracted from the flowers and leaves of $P$. spinosa, examine their anti-proliferative activity and characterize their effect on inducing apoptosis and cell cycle arrest against two different breast cancer cell lines MCF-7 and MDA-MB-231.

In this study, the essential oils were extracted from flowers and leaves of $P$. spinosa by hydrodistillation and SPME to determine their chemical composition by GC and GC- 


\section{Cellular Physiology Cell Physiol Biochem 2017;42:2043-2065

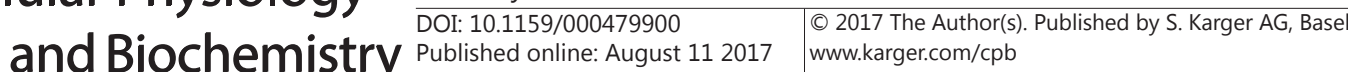 \\ Saleh et al.: Anticancer Activity of $P$. Spinosa Essential Oils}

MS analysis. Our oil yields by hydrodistillation are higher than that reported by Senatore and Bruno [21] from the flower-heads of the same plant collected in Italy. Their chemical investigations show that the flower-heads oil is dominated by oxygenated sesquiterpenes, amounting to $60.2 \%$ of the total composition. The main components in this group include germacra-1(10),5-dien-3,4-diol (18.4\%), $\alpha$-cadinol (14.1\%), 3-acetoxygermacra-1(10),5dien-4-ol (13.0\%) and T-cadinol (8.2\%). In contrast, the oxygenated sesquiterpenes constitute $78.63 \%$ of all compounds in our F-PSEO as compared to the previous report [21]. Furthermore, F-PSEO contains acorenone B (33.85\%), $\alpha$-muurolol $(21.93 \%), \alpha$-cadinol (8.54\%), oplopanonyl acetate (7.22\%), $\delta$-cadinene (4.95\%) and germacrene-D-4-ol (4.28\%) as the major oxygenated sesquiterpenes. The variation in the essential oil content and chemical composition is attributed to well-known factors including geographical location, age of the plant, climate, cultivar and methods of distillation employed [17]. Notably, the comparison between the chemical composition of the leaf and flower oil of $P$. spinosa is only recorded in the present report. L-PSEO contains two groups of compounds: oxygenated sesquiterpenes $(51.60 \%)$ and sesquiterpene hydrocarbons $(34.06 \%)$. The oxygenated sesquiterpenes [ $\alpha$-cadinol (13.15\%), acorenone B (9.64\%) and $\alpha$-muurolol $(9.83 \%)]$ and the sesquiterpene hydrocarbons [ $\beta$-longipinene $(6.26 \%)$ and $\delta$-Cadinene $(5.79 \%)]$ were the most abundant compounds of these two groups in leaf oil.

SPME technique is able to extract and concentrate analytes of different volatility, including trace essential oil substances from a very little amount of plant material [17]. In addition, the extraction in this method is performed at low temperatures, hence, the potential thermal degradation of some compounds is negligible when compared to hydrodistillation. Therefore, SPME is preferred over hydrodistillation for detailed GC-MS analytical purposes. In this view, we have compared the composition of the volatile oils extracted by SPME and hydrodistillation. The percentage of monoterpene hydrocarbons, sesquiterpene hydrocarbons and oxygenated monoterpenes are detected at higher concentrations in both F-PSEO and L-PSEO extracted by SPME when compared to hydrodistillation. Conversely, hydrodistilled oils contain more oxygenated sesquiterpenes than that of SPME flower and leaf samples, indicating the high efficiency of hydrodistillation in extracting this group of compounds [17].

Several previous studies have shown that many plant essential oils possess a potent anticancer activity against different cancer cell lines [38-42]. Particularly, plant essential oils from the Asteraceae family are characterized by high contents of cytotoxic oxygenated sesquiterpenes, monoterpenes and monocyclic monoterpenes [43]. Essential oils from members of this family, includes Inula helenium, Inula racemose and Inula japonica which all contain high percentages of the sesquiterpene lactone isoalantolactone [44], and are widely used in Chinese medicine as they have been shown to possess a strong antiproliferative effect against a wide-spectrum of tumor cell lines [44,45]. Recently, it has been demonstrated that the essential oil from Inula japonica sensitizes the multidrug resistant (MDR) MCF-7/ADR cells to doxorubicin induced apoptosis by down-regulating $A B C B 1$ expression and reducing lipid raft stability [46]. We have also shown that the essential oil from the aerial parts of Artemisia vulgaris L. induces apoptosis in the human acute myelogenous leukemia cell line HL-60 by triggering the release of cytochrome $\mathrm{c}$ from mitochondria to activate the APAF1 /caspase-9 apoptosome [31]. In addition to HL-60, low doses of $A$. vulgaris volatile oil are able to inhibit the growth of other hematological (Jurkat, K562) and solid tumor (MCF-7, HepG2, PC-3 and HeLa), but lack substantial cytotoxicity against normal immortalized cells such as BJ and HEK-293 V79-4 [31]. Low concentrations of oil from the leaves of Artemisia herba alba have been reported to strongly inhibit the growth of P815 mastocytoma and BSR kidney carcinoma cell line, but not normal human peripheral blood mononuclear cells [47]. Moreover, A. herba alba and A. campestris are able to kill Leishmania infantum promastigotes through induction of apoptosis and halting cells at G0/G1 phase [48]. Furthermore, the sesquiterpenoid hinesol isolated from the essential oil of Atractylodes lancea rhizome induces apoptosis through the c-Jun N-terminal kinase (JNK) signaling pathway in HL-60 cells [49]. 


\section{Cellular Physiology Cell Physiol Biochem 2017;42:2043-2065

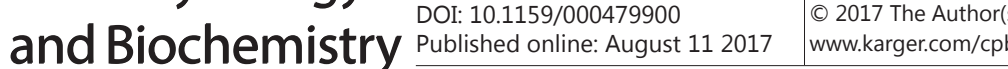 \\ Saleh et al.: Anticancer Activity of $P$. Spinosa Essential Oils}

In line with the above studies, we show here that the essential oils extracted from flowers and leaves of P. spinosa (Asteraceae family) exhibit a strong and selective cytotoxic activity against the ER-positive MCF-7 and ER-negative MDA-MB-231 breast cancer cells. Importantly, all the tested doses of either oil demonstrate that F-PSEO is a more potent inhibitor of cellular growth than L-PSEO, with $\mathrm{IC}_{50}$ values that are $\sim 10$-times and $\sim 7$-times less than the ones for L-PSEO in MCF-7 and MDA-MB-231 cells, respectively. The differences between the $\mathrm{IC}_{50}$ values of F-PSEO and L-PSEO are attributed to both compositional and quantitative variations among these oils. The cyclic monoterpene $p$-cymene, that constitutes a $27.76 \%$ (by SPME, $1.33 \%$ by hydrodistillation) of the flower oil compared to $5.56 \%$ (SPME, 0.1\%-hydrodistillation) in L-PSEO, has been reported to exhibit strong antitumor invasive and metastatic actions towards the human fibrosarcoma HT-1080 cells through inhibition of matrix metalloproteinase 9 (MMP-9) along with the suppression of ERK1/2 and p38 MAPK [50]. The cyclic monoterpene $\alpha$-phellandrene, comprises 13.59\% (SPME, $1.74 \%$-hydrodistillation, compared to $1.08 \%$ and $0.36 \%$ in L-PSEO, respectively), induces apoptosis through the mitochondria-dependent pathway, cell cycle arrest at G0/G1 phase and production of reactive oxygen species (ROS) in murine WEHI-3 leukemic cells [51]. $\alpha$-phellandrene also alters the expression of cell cycle checkpoint genes such as cyclin G2 and the CDK inhibitor p21, in addition to several apoptosis regulatory factors including caspases [52]. Hsieh LC et al [53] have demonstrated that sub-micromolar concentrations of $\alpha$-phellandrene promote cell death by autophagy through modulating the expression of mTOR and LC-3II, p53 signaling, and NF- $\kappa$ B activation in J5 liver tumor cells. In addition, the toxicity of this compound involves necrosis when tested in liver cancer cell lines [54]. Furthermore, there is a 12-fold higher percentage of the sesquiterpene hydrocarbon E-caryophyllene in F-PSEO than L-PSEO. This component has been shown to trigger typical morphological changes of apoptosis including nuclear condensation and nucleosomal DNA fragmentation, in addition to inhibition of migration and invasion of colorectal cancer cell lines [55]. Therefore, the more potent anti-proliferative activity of F-PSEO is most probably related to the presence of these strong cytotoxic agents in higher concentrations than the counterparts in L-PSEO, and their potential synergetic actions together with other minor bioactive constituents that are different among the two oils.

On the other hand, the cytotoxicity of the F-PSEO in the non-cancerous epithelial mammary cells MCF-10-2A is $~ 5$ to 6-times less than the one in MCF-7 and MDA-MB-231 cells, suggesting a better efficacy of the oil against tumor cells. The differential effect of F-PSEO between these cell lines may be related to variations in the genetic profile, specific gene expression and distinct cell surface receptors of cancer cells making them more susceptible to the oil [56].

Cell death may occur by many ways such as necrosis, autophagy, mitotic catastrophe, senescence and apoptosis [57]. Apoptosis is the most common and well understood mechanism employed by the cytotoxic agents including plant essential oils [38]. To study the possibility of apoptosis mediated cell death caused by the oils, we have performed a quantitative analysis of apoptosis using Annexin-V/7AAD flow cytometry analysis. Our results show that $\sim 80-90 \%$ of MCF-7 and MDA-MB-231 cell population are in early and late stages of apoptosis after exposure to $1.0 \mu \mathrm{g} / \mathrm{mL}$ of F-PSEO, compared to $~ 30-50 \%$ apoptotic cells seen with a similar concentration of L-PSEO. Importantly, necrosis is no greater than $10 \%$ under all the tested conditions. Indeed, blocking necrotic cell death with necrostatin-1 did not affect induction of apoptosis by either oil (not shown). In addition, both oils induce typical apoptotic morphological changes in MCF-7 and MDA-MB-231 cells including loss of cellular shape and shrinkage, nuclear condensation and fragmentation. Furthermore, F-PSEO and L-PSEO trigger activation of the effector caspase-3/-7 that typically mediate and execute apoptotic cell death, by cleaving/inactivating essential target proteins required for cell growth and division such as PARP that is evident in our results. Taken together, these findings clearly indicate that both flower and leaf volatile oil of $P$. spinosa induce cell death in MCF-7 and MDA-MB-231 breast carcinoma cells by apoptosis rather than necrosis and, therefore, consistent with the goal of a potential anticancer agent. 


\section{Cellular Physiology Cell Physiol Biochem 2017;42:2043-2065

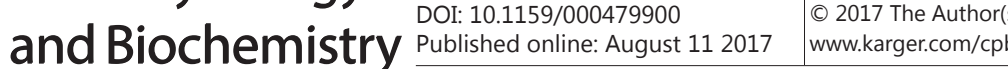 \\ Saleh et al.: Anticancer Activity of $P$. Spinosa Essential Oils}

Treatment of MCF-7 and MDA-MB-231 cells with F-PSEO or L-PSEO triggers a dosedependent activation of executioner caspase-3/-7, implying only a mechanism of caspasemediated cell death. However, our finding that z-VAD-FMK only partially rescued the oiltreated cells from apoptosis suggests the possible involvement of caspase-independent pathways of cell death. This is particularly obvious with the finding that the general caspaseinhibitor is only able to reverse $\sim 30 \%$ of the oil induced apoptosis in MDA-MB-231 compared to $\sim 60 \%$ in MCF-7 cells. The fact that the essential oils of $P$. spinosa contain compounds that promote cell death by autophagy [53], activation of MAPKs [50], production of ROS [51] and cell cycle arrest [51], proposes that they may also contribute to the cytotoxicity of F-PSEO and L-PSEO.

Apoptosis is triggered by two different mechanisms: one is mediated by the cell surface death receptor (extrinsic pathway), while the other (intrinsic pathway) depends on the release of mitochondrial apoptogenic factors such as cytochrome c and AIF [57]. Although the pathway involved in P. spinosa essential oil induced-apoptosis remains to be identified, our results strongly suggest the involvement of the mitochondria in this process. Modulation of pro- and anti-apoptotic protein levels of Bcl-2 family members serves as a key regulator for the release of mitochondrial apoptogenic factors. Pro-apoptotic proteins of the BH3 group, Bax and Bak, inhibit the anti-apoptotic activity of BH4 group proteins, $\mathrm{Bcl}-2$ and $\mathrm{Bcl}-\mathrm{X}_{\mathrm{L}}$, by forming heterodimers and exhibit pro-apoptotic activity by forming homodimers [34]. The change in ratio of Bax/Bcl-2 or Bak/ Bcl- $\mathrm{x}_{\mathrm{L}}$ causes channel formation in the mitochondrial outer membrane and subsequent release of cytochrome $c$ which eventually leads to caspase-3 activation resulting in cell death via apoptosis $[34,58,59]$. Indeed, both F-PSEO and L-PSEO increase the Bax/Bcl-2 ratio by reducing Bcl-2 and elevating Bax levels with increasing doses. This will allow Bax to form the homodimer channels in the outer mitochondrial membrane causing the translocation of cytochrome $\mathrm{c}$ to the cytoplasm to promote caspase activation.

Several plant essential oils have been shown to arrest cell cycle, leading to cell death, by modulating the expression or inhibiting the activities of cell cycle regulatory proteins [60]. We thus analyzed the effect of F-PSEO and L-PSEO on cell cycle checkpoint regulation. The lavender essential oil extracted from Lavandula angustifolia contains high percentages of linalool and linalyl acetate, which induce apoptosis and the arrest at G2/M phase of cell cycle in PC3 and DU145 prostate cancer cells [61]. Kumar and coworkers [62] have demonstrated that the essential oils from leaves and flowers of Callistemon citrinus inhibit cell cycle progression at S and G2/M phases in human lung carcinoma (A549) and rat glioma (C-6) cells. In addition, the Asteraceae Artemisia campestris and Artemisia herba-alba essential oils effectively kill Leishmania promastigotes by apoptosis and halting cell cycle at G0/G1 stage [48]. Here we show that F-PSEO and L-PSEO inhibit cell cycle progression and induces cellcycle arrest in the G0/G1 phase in MCF-7 and MDA-MB-231 cells in a dose-dependent manner. Similarly to the demonstrated effects as apoptotic inducer, F-PSEO was more powerful in inhibiting cell cycle progression than L-PSEO. Furthermore, MDA-MB-231 cells are found to be more affected by this inhibition than MCF-7 cells. Taken together, these findings indicate that the cytotoxicity of $P$. spinosa essential oils is mediated by apoptosis and cell cycle arrest.

Overexpression of cyclin D1 is associated with the development, progression and metastasis of human mammary carcinomas [63]. Cyclin D1 forms different protein-protein interactions with key cell growth regulators, among which is CDK4, which is also overexpressed in significant number of breast cancer cases $[64,65]$. In addition, it has been reported that elevated CDK4 phosphorylation activity is required to maintain the tumorigenesis of breast cancer cells [66]. Therefore, disruption of the functional association between cyclin D1 and CDK4 has been proposed as a target for therapeutic intervention in breast cancer [67]. The major sesquiterpene lactones deoxyelephantopin derived from Elephantopus scabe induces apoptosis and inhibits cell cycle progression of HCT116 colorectal cancer cells through downregulating cyclin D1 and CDK4 protein expression [68]. Boswellic acids, extracted from Boswellia sacra essential oil have been shown to suppress the expression of cyclin D1, cyclin $\mathrm{E}, \mathrm{CDK} 2$ and CDK4, as well as inhibit the phosphorylation of retinoblastoma protein RB, and increase production of p21 [69-71]. Consistent with these findings, our results demonstrate 


\section{Cellular Physiology Cell Physiol Biochem 2017;42:2043-2065

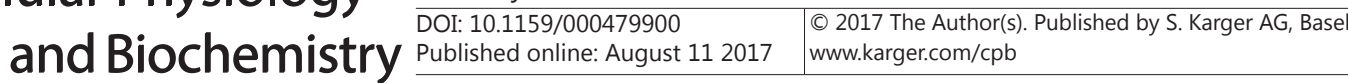 \\ Saleh et al.: Anticancer Activity of $P$. Spinosa Essential Oils}

that increased concentrations of either F-PSEO and L-PSEO suppress the expression of cyclin D1 and CDK4 in MDA-MB-231 cells. Therefore, components of $P$. spinosa essential oil, particularly F-PSEO which has a stronger effect on cyclin D1 and CDK4 than L-PSEO, could represent potential chemotherapeutic agents targeting the uncontrolled progression from G1 to S phase in mammary carcinomas.

This study concludes that the selective cytotoxicity of the essential oils extracted from $P$. spinosa flowers and leaves is mediated by apoptosis and cell cycle arrest. The presence of highly active phytochemicals like the cyclic monoterpenes $p$-cymene and $\alpha$-phellandrene, and the sesquiterpene hydrocarbon E-caryophyllene in these oils may serve as potent natural anticancer compounds to improve human health. The flower oil showed a stronger promising activity on both ER-positive (MCF-7) and ER-negative (MDA-MB-231) cancer cells than the leaf oil, probably due to its higher contents of these bioactive compounds. When compared to the breast cancer cells, the finding that much greater concentrations of both oils are required to inhibit the growth of the non-cancerous mammary cells MCF-10$2 \mathrm{~A}$ and $\mathrm{PB}-\mathrm{MNCs}$ suggests their efficacy and warrant further investigations for potential pharmaceutical application.

\section{Ethics Statement}

P. spinosa is neither an endangered nor a protected species in Jordan. Cytotoxicity assay using human peripheral blood mononuclear cells (PB-MNCs) was approved by the Institutional Review Board (IRB, under the protocol number RC12/159) of KAIMRC. Written consent as per the standard operating procedure of King Abdulaaziz Medical City was obtained from the volunteer before collection of the blood samples.

\section{Abbreviations}

F-PSEO (Pallines spinosa flower essential oil); L-PSEO (Pallines spinosa leaf essential oil); GC (gas chromatography); GC-MS (gas chromatography-coupled mass spectrometry); GCFID (gas chromatography-flame ionization detector); SPME (solid phase microextraction); RI (retention index); PB-MNCs (peripheral blood mononuclear cells); Bcl-2 (B-cell lymphoma 2); Bcl-xL (B-cell lymphoma-extra-large); Bax (Bcl-2-associated X protein); Bak (Bcl-2 homologous antagonist killer); PARP (Poly (ADP-ribose) polymerase); CDK (cyclin dependent kinase); CKI (cyclin dependent kinase inhibitor); p21 $1^{\text {WAF1/CIP1 }}$ (cyclin-dependent kinase inhibitor 1 or CDK-interacting protein 1, simply used here as p21); p27 ${ }^{\mathrm{KIP} 1}$ (cyclindependent kinase inhibitor $1 \mathrm{~B}$ or Kinase inhibitory protein, simply used here as $\mathrm{p} 27$ ); z-VADFMK (N-Benzyloxycarbonyl-Val-Ala-Asp-fluoromethyl ketone); Ac-DEVD-pNA (N-acetylAsp-Glu-Val-Asp-p-nitroanilide); pNA (p-nitroanilide).

\section{Acknowledgments}

This project is gratefully supported by a research grant from King Abdullah International Medical Research Center (KAIMRC; Grant number- RC/12/159, Riyadh, Kingdom of Saudi Arabia) for Saleh AM. Al-Qudah MA is supported by the Deanship of Scientific Research and Graduate Studies (Grant number 2/2013, Yarmouk University, Irbid, The Hashemite Kingdom of Jordan).

\section{Disclosure Statement}

The authors declare no conflict of interest.

\section{References}

1 Society AC: Cancer Facts \& Figures 2017. Atlanta, Ga, American Cancer Society 2017. 


\section{Cellular Physiology Cell Physiol Biochem 2017;42:2043-2065 \begin{tabular}{ll|l} 
and Biochemistry $10.1159 / 000479900$ & $\begin{array}{l}\text { P } 2017 \text { The Author(s). Published by S. Karger AG, Basel } \\
\text { www.karger.com/cpb }\end{array}$
\end{tabular}}

Saleh et al.: Anticancer Activity of $P$. Spinosa Essential Oils

-2 Allemani C, Weir HK, Carreira H, Harewood R, Spika D, Wang X-S, Bannon F, Ahn JV, Johnson CJ, Bonaventure A: Global surveillance of cancer survival 1995-2009: analysis of individual data for 25676 887 patients from 279 population-based registries in 67 countries (CONCORD-2). Lancet 2015;385:9771010.

-3 Wong RS: Apoptosis in cancer: from pathogenesis to treatment. J Exp Clin Cancer Res 2011;30:87.

4 Zhu A, Li Y, Song W, Xu Y, Yang F, Zhang W, Yin Y, Guan X: Antiproliferative Effect of Androgen Receptor Inhibition in Mesenchymal Stem-Like Triple-Negative Breast Cancer. Cell Physiol Biochem 2016;38:10031014.

5 Zhao S, Han J, Zheng L, Yang Z, Zhao L, Lv Y: MicroRNA-203 Regulates Growth and Metastasis of Breast Cancer. Cell Physiol Biochem 2015;37:35-42.

6 Gupta S, George M, Singhal M, Sharma GN, Garg V: Leaves extract of Murraya Koenigii linn for antiinflammatory and analgesic activity in animal models. J Adv Pharm Tech Res 2010;1:68-77.

7 Hassan MSU, Ansari J, Spooner D, Hussain SA: Chemotherapy for breast cancer (Review). ONCOL REP 2010;24:1121-1131.

8 Carpenter RL, Lo H-W: Regulation of Apoptosis by HER2 in Breast Cancer. J Carcinog Mutagen 2013;2013:003.

-9 Zhou BP, Hu MC-T, Miller SA, Yu Z, Xia W, Lin S-Y, Hung M-C: HER-2/neu Blocks Tumor Necrosis Factorinduced Apoptosis via the Akt/NF-кB Pathway. J Biol Chem 2000;275:8027-8031.

10 Cuello M, Ettenberg SA, Clark AS, Keane MM, Posner RH, Nau MM, Dennis PA, Lipkowitz S: DownRegulation of the erbB-2 Receptor by Trastuzumab (Herceptin) Enhances Tumor Necrosis Factor-related Apoptosis-inducing Ligand-mediated Apoptosis in Breast and Ovarian Cancer Cell Lines that Overexpress erbB-2. Cancer Res 2001;61:4892-4900.

-11 Siddiqa A, Long LM, Li L, Marciniak RA, Kazhdan I: Expression of HER-2 in MCF-7 breast cancer cells modulates anti-apoptotic proteins Survivin and Bcl-2 via the extracellular signal-related kinase (ERK) and phosphoinositide-3 kinase (PI3K) signalling pathways. BMC Cancer 2008;8:129.

12 Ding Y, Liu Z, Desai S, Zhao Y, Liu H, Pannell LK, Yi H, Wright ER, Owen LB, Dean-Colomb W, Fodstad O, Lu J, LeDoux SP, Wilson GL, Tan M: Receptor Tyrosine Kinase ErbB2 Translocates into Mitochondria and Regulates Cellular Metabolism. Nat Commun 2012;3:1271.

-13 Zhou BP, Liao Y, Xia W, Zou Y, Spohn B, Hung M-C: HER-2/neu induces p53 ubiquitination via Akt-mediated MDM2 phosphorylation. Nat Cell Biol 2001;3:973-982.

14 Diaz-Moralli S, Tarrado-Castellarnau M, Miranda A, Cascante M: Targeting cell cycle regulation in cancer therapy. Pharmacol Ther 2013;138:255-271.

15 Cechinel-Filho V: Natural products as lead compounds in medicinal chemistry. Barreiro EJ, Fraga CAM, Lima LM (eds): Plant bioactives and drug discovery: principles, practice, and perspectives Hoboken, John Wiley \& Sons 2012;17:81-126.

16 Russo R, Corasaniti MT, Bagetta G, Morrone LA: Exploitation of Cytotoxicity of Some Essential Oils for Translation in Cancer Therapy. EVID-BASED COMPL ALT 2015;e397821.

17 Vichi S, Guadayol JM, Caixach J, López-Tamames E, Buxaderas S: Comparative study of different extraction techniques for the analysis of virgin olive oil aroma. Food Chem 2007;105:1171-1178.

18 Al-Eisawi DM: List of Jordan vascular plants. Amman 1982;152:79-182.

19 Cavero RY, Calvo MI: Medicinal plants used for musculoskeletal disorders in Navarra and their pharmacological validation. J Ethnopharmacol 2015;168:255-259.

20 Chermat S, Gharzouli R: Ethnobotanical study of medicinal flora in the North East of Algeria-An empirical knowledge in Djebel Zdimm (Setif). J Mater Sci Eng 2015;5:50-59.

21 Senatore F, Bruno M: Composition of the essential oil of Pallenis spinosa (L.) Cass. (Asteraceae). Flavour Fragr J 2003;18:195-197.

22 Al-Qudah MA: Antioxidant Acitvity and Chemical Composition of Essential Oils of Fresh and Air-dried Jordanian Nepeta curviflora Boiss. Journal of Biologically Active Products from Nature 2016;6:101-111.

23 Adams RP: Identification of Essential Oil Components by Gas Chromatography/Mass Spectroscopy. J Am Soc Mass Spectrom 1997;6:671-672.

24 SE S (ed) National Institute of Standards and Technology (NIST) Mass Spectral Database and Software, Gaithersburg, Maryland, USA, 1990, vol Version 3.02.

-25 Saleh AM, Taha MO, Aziz MA, Al-Qudah MA, AbuTayeh RF, Rizvi SA: Novel anticancer compound [trifluoromethyl-substituted pyrazole N-nucleoside] inhibits FLT3 activity to induce differentiation in acute myeloid leukemia cells. Cancer Lett 2016;375:199-208.

-26 Saleh AM, Aljada A, El-Abadelah MM, Sabri SS, Zahra JA, Nasr A, Aziz MA: The Pyridone-Annelated Isoindigo (5'-Cl) Induces Apoptosis, Dysregulation of Mitochondria and Formation of ROS in Leukemic HL-60 Cells. Cell Physiol Biochem 2015;35:1958-1974.

27 Saleh AM, El-Abadelah MM, Aziz MA, Taha MO, Nasr A, Rizvi SAA: Antiproliferative activity of the isoindigo 


\section{Cellular Physiology Cell Physiol Biochem 2017;42:2043-2065 \begin{tabular}{ll|l} 
and Biochemistry 2017 The Author(s). Published by S. Karger AG, Basel \\
Published onlne: August 112017 & $\begin{array}{l}\text { (1159/00047990 } \\
\text { www.karger.com/cpb }\end{array}$ \\
\hline
\end{tabular}}

Saleh et al.: Anticancer Activity of $P$. Spinosa Essential Oils

5'-Br in HL-60 cells is mediated by apoptosis, dysregulation of mitochondrial functions and arresting cell cycle at G0/G1 phase. Cancer Lett 2015;361:251-261.

28 Saleh AM, Aziz MA, Abdou IM, Taha MO, Al-Qudah MA, Abadleh MM, Aljada A, Rizvi SA: Cytotoxic activity of the novel heterocyclic compound G-11 is primarily mediated through intrinsic apoptotic pathway. APOPTOSIS 2016;21:873-886.

29 Saleh AM, Aljada A, El-Abadelah MM, Taha MO, Sabri SS, Zahra JA, Aziz MA: The Anticancer Activity of the Substituted Pyridone-Annelated Isoindigo (5'-Cl) Involves G0/G1 Cell Cycle Arrest and Inactivation of CDKs in the Promyelocytic Leukemia Cell Line HL-60. Cell Physiol Biochem 2015;35:1943-1957.

-30 Chen CC, Chen Y, Hsi Y-T, Chang C-S, Huang L-F, Ho C-T, Way T-D, Kao J-Y: Chemical Constituents and Anticancer Activity of Curcuma zedoaria Roscoe Essential Oil against Non-Small Cell Lung Carcinoma Cells in Vitro and in Vivo. J Agric Food Chem 2013;61:11418-11427.

-31 Saleh AM, Aljada A, Rizvi SA, Nasr A, Alaskar AS, Williams JD: In vitro cytotoxicity of Artemisia vulgaris L. essential oil is mediated by a mitochondria-dependent apoptosis in HL-60 leukemic cell line. BMC Complement Altern Med 2014;14:226.

-32 Catalani S, Palma F, Battistelli S, Benedetti S: Oxidative stress and apoptosis induction in human thyroid carcinoma cells exposed to the essential oil from Pistacia lentiscus aerial parts. PLoS One 2017;12:e0172138.

33 Alnemri ES: Mammalian cell death proteases: A family of highly conserved aspartate specific cysteine proteases. J Cell Biochem 1997;64:33-42.

-34 Kuwana T, Newmeyer DD: Bcl-2-family proteins and the role of mitochondria in apoptosis. Curr Opin Cell Biol 2003;15:691-699.

- 35 Seal S, Chatterjee P, Bhattacharya S, Pal D, Dasgupta S, Kundu R, Mukherjee S, Bhattacharya S, Bhuyan M, Bhattacharyya PR, Baishya G, Barua NC, Baruah PK, Rao PG, Bhattacharya S: Vapor of Volatile Oils from Litsea cubeba Seed Induces Apoptosis and Causes Cell Cycle Arrest in Lung Cancer Cells. PLoS One 2012;7:e47014.

-36 Chang W-L, Cheng F-C, Wang S-P, Chou S-T, Shih Y: Cinnamomum cassia essential oil and its major constituent cinnamaldehyde induced cell cycle arrest and apoptosis in human oral squamous cell carcinoma HSC-3 cells. Environ Toxicol 2017;32:456-468.

-37 Cragg GM, Newman DJ: Plants as a source of anti-cancer agents. J Ethnopharmacol 2005;100:72-79.

-38 Gautam N, Mantha AK, Mittal S: Essential Oils and Their Constituents as Anticancer Agents: A Mechanistic View. Biomed Res Int 2014;2014:e154106.

-39 Yun M, Lee D, Park M-N, Kim E-O, Sohn EJ, Kwon B-M: Cinnamaldehyde derivative (CB-PIC) sensitizes chemo-resistant cancer cells to drug-induced apoptosis via suppression of MDR1 and its upstream STAT3 and AKT signalling. Cell Physiol Biochem 2015;35:1821-1830.

-40 Karimian H, Fadaeinasab M, Moghadamtousi SZ, Hajrezaei M, Zahedifard M, Razavi M, Safi SZ, Mohan S, Khalifa SA, El-Seedi HR, Abdulla MA, Ali HM, Noordin MI: The Chemopreventive Effect of Tanacetum Polycephalum Against LA7-Induced Breast Cancer in Rats and the Apoptotic Effect of a Cytotoxic Sesquiterpene Lactone in MCF7 Cells: A Bioassay-Guided Approach. Cell Physiol Biochem 2015;36:9881003.

-41 Sun D-W, Zhang H-D, Mao L, Mao C-F, Chen W, Cui M, Ma R, Cao H-X, Jing C-W, Wang Z: Luteolin inhibits breast cancer development and progression in vitro and in vivo by suppressing notch signaling and regulating miRNAs. Cell Physiol Biochem 2015;37:1693-1711.

-42 Zhang H-Y, Liang F, Wang F, Zhang J-W, Wang L, Kang X-G, Wang J, Duan Q-L: In Vitro Effects of HAS-2 Gene Silencing on the Proliferation and Apoptosis of the MCF-7 Human Breast Cancer Cell Line. Cell Physiol Biochem 2016;40:807-817.

43 Hamid A, Aiyelaagbe O, Usman L: Essential oils: its medicinal and pharmacological uses. Int J Cur Res 2011;33:86-98.

44 Yang C, Wang C-M, Jia Z-J: Sesquiterpenes and Other Constituents from the Aerial Parts of Inula japonica. Planta Med 2003;69:662-666.

45 Li Y, Ni Z-Y, Zhu M-C, Dong M, Wang S-M, Shi Q-W, Zhang M-L, Wang Y-F, Huo C-h, Kiyota H, Cong B: Antitumour Activities of Sesquiterpene Lactones from Inula helenium and Inula japonica. Z Naturforsch C C 2014;67:375-380.

46 Wu M, Li T, Chen L, Peng S, Liao W, Bai R, Zhao X, Yang H, Wu C, Zeng H, Liu Y: Essential oils from Inula japonica and Angelicae dahuricae enhance sensitivity of MCF-7/ADR breast cancer cells to doxorubicin via multiple mechanisms. J Ethnopharmacol 2016;180:18-27.

-47 Tilaoui M, Mouse HA, Jaafari A, Zyad A: Comparative Phytochemical Analysis of Essential Oils from Different Biological Parts of Artemisia herba alba and Their Cytotoxic Effect on Cancer Cells. PLoS One 2015;10:e0131799.

48 Aloui Z, Messaoud C, Haoues M, Neffati N, Bassoumi Jamoussi I, Essafi-Benkhadir K, Boussaid M, Guizani I, 


\section{Cellular Physiology Cell Physiol Biochem 2017;42:2043-2065

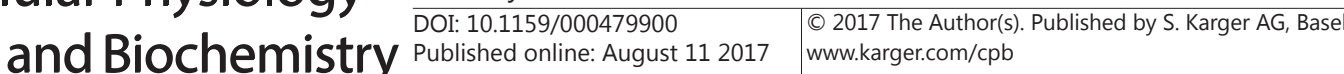

Saleh et al.: Anticancer Activity of $P$. Spinosa Essential Oils

Karoui H: Asteraceae Artemisia campestris and Artemisia herba-alba Essential Oils Trigger Apoptosis and Cell Cycle Arrest in Leishmania infantum Promastigotes. EVID-BASED COMPL ALT 2016;2016:e9147096.

49 Masuda Y, Kadokura T, Ishii M, Takada K, Kitajima J: Hinesol, a compound isolated from the essential oils of Atractylodes lancea rhizome, inhibits cell growth and induces apoptosis in human leukemia HL-60 cells. J Nat Med 2015;69:332-339.

-50 Li J, Liu C, Sato T: Novel Antitumor Invasive Actions of p-Cymene by Decreasing MMP-9/TIMP-1 Expression Ratio in Human Fibrosarcoma HT-1080 Cells. Biol Pharm Bull 2016;39:1247-1253.

-51 Lin J-J, Hsu S-C, Lu K-W, Ma Y-S, Wu C-C, Lu H-F, Chen J-C, Lin J-G, Wu P-P, Chung J-G: Alpha-phellandreneinduced apoptosis in mice leukemia WEHI-3 cells in vitro. Environ Toxicol 2016;31:1640-1651.

52 Lin J-J, Yu C-C, Lu K-W, Chang S-J, Yu F-S, Liao C-L, Lin J-G, Chung J-G: $\alpha$-Phellandrene Alters Expression of Genes Associated with DNA Damage, Cell Cycle, and Apoptosis in Murine Leukemia WEHI-3 Cells. Anticancer Res 2014;34:4161-4180.

-53 Hsieh L-C, Hsieh S-L, Chen C-T, Chung J-G, Wang J-J, Wu C-C: Induction of $\alpha$-Phellandrene on Autophagy in Human Liver Tumor Cells. Am J Chin Med 2015;43:121-136.

54 Hsieh S-L, Li Y-C, Chang W-C, Chung J-G, Hsieh L-C, Wu C-C: Induction of Necrosis in Human Liver Tumor Cells by $\alpha$-Phellandrene. Nutr Cancer 2014;66:970-979.

-55 Dahham SS, Tabana YM, Iqbal MA, Ahamed MBK, Ezzat MO, Majid ASA, Majid AMSA: The Anticancer, Antioxidant and Antimicrobial Properties of the Sesquiterpene $\beta$-Caryophyllene from the Essential Oil of Aquilaria crassna. MOLECULES 2015;20:11808-11829.

-56 Charafe-Jauffret E, Ginestier C, Monville F, Finetti P, Adélaïde J, Cervera N, Fekairi S, Xerri L, Jacquemier J, Birnbaum D, Bertucci F: Gene expression profiling of breast cell lines identifies potential new basal markers. Oncogene 2005;25:2273-2284.

57 Sampath D, Rao VA, Plunkett W: Mechanisms of apoptosis induction by nucleoside analogs. Oncogene 2003;22:9063-9074.

58 Adams JM, Cory S: Apoptosomes: engines for caspase activation. Curr Opin Cell Biol 2002;14:715-720.

-59 Groninger E, Meeuwsen-De Boer GJ, De Graaf SSN, Kamps WA, De Bont ESJM: Vincristine induced apoptosis in acute lymphoblastic leukaemia cells: a mitochondrial controlled pathway regulated by reactive oxygen species? Int J Oncol 2002;21:1339-1345.

60 Singh RP, Dhanalakshmi S, Agarwal R: Phytochemicals as Cell Cycle Modulators A Less Toxic Approach in Halting Human Cancers. Cell Cycle 2002;1:155-160.

61 Zhao Y, Chen R, Wang Y, Qing C, Wang W, Yang Y: In Vitro and In Vivo Efficacy Studies of Lavender angustifolia Essential Oil and Its Active Constituents on the Proliferation of Human Prostate Cancer. Integr Cancer Ther 2016;16:215-226.

62 Kumar D, Sukapaka M, Babu GDK, Padwad Y: Chemical Composition and In Vitro Cytotoxicity of Essential Oils from Leaves and Flowers of Callistemon citrinus from Western Himalayas. PLoS One 2015;10:e0133823.

63 Gillett C, Fantl V, Smith R, Fisher C, Bartek J, Dickson C, Barnes D, Peters G: Amplification and Overexpression of Cyclin D1 in Breast Cancer Detected by Immunohistochemical Staining. Cancer Res 1994;54:1812-1817.

64 Bartkova J, Lukas J, Müller H, Lützhøt D, Strauss M, Bartek J: Cyclin D1 protein expression and function in human breast cancer. INT J CANCER 1994;57:353-361.

65 Gillett C, Smith P, Gregory W, Richards M, Millis R, Peters G, Barnes D: Cyclin D1 and prognosis in human breast cancer. INT J CANCER 1996;69:92-99.

66 Takano Y, Takenaka H, Kato Y, Masuda M, Mikami T, Saegusa M, Okayasu I: Cyclin D1 overexpression in invasive breast cancers: correlation with cyclin-dependent kinase 4 and oestrogen receptor overexpression, and lack of correlation with mitotic activity. J Cancer Res Clin Oncol 1999;125:505-512.

-67 Yu Q Sicinska E, Geng Y, Ahnström M, Zagozdzon A, Kong Y, Gardner H, Kiyokawa H, Harris LN, Stål O, Sicinski P: Requirement for CDK4 kinase function in breast cancer. Cancer Cell 2006;9:23-32.

68 Chan CK, Chan G, Awang K, Abdul Kadir H: Deoxyelephantopin from Elephantopus scaber Inhibits HCT116 Human Colorectal Carcinoma Cell Growth through Apoptosis and Cell Cycle Arrest. MOLECULES 2016;21:385.

69 Syrovets T, Gschwend JE, Büchele B, Laumonnier Y, Zugmaier W, Genze F, Simmet T: Inhibition of IкB Kinase Activity by Acetyl-boswellic Acids Promotes Apoptosis in Androgen-independent PC-3 Prostate Cancer Cells in Vitro and in Vivo. J BIOL CHEM 2005;280:6170-6180.

70 Liu J-J, Huang B, Hooi SC: Acetyl-keto- $\beta$-boswellic acid inhibits cellular proliferation through a p21dependent pathway in colon cancer cells. Br J Pharmacol 2006;148:1099-1107.

-71 Suhail MM, Wu W, Cao A, Mondalek FG, Fung K-M, Shih P-T, Fang Y-T, Woolley C, Young G, Lin H-K: Boswellia sacra essential oil induces tumor cell-specific apoptosis and suppresses tumor aggressiveness in cultured human breast cancer cells. BMC Complement Altern Med 2011;11:129. 